\title{
EMPLOYER MATCHING AND 401(K) SAVING: EVIDENCE FROM THE HEALTH AND RETIREMENT STUDY
}

\author{
Gary V. Engelhardt* \\ Anil Kumar \\ CRR WP 2004-18 \\ Released: May 2004 \\ Draft Submitted: April 2004 \\ Center for Retirement Research at Boston College \\ 550 Fulton Hall \\ 140 Commonwealth Ave. \\ Chestnut Hill, MA 02467 \\ Tel: 617-552-1762 Fax: 617-552-1750 \\ http://www.bc.edu/crr
}

*Gary V. Engelhardt is an associate professor of economics at Syracuse University and a senior research associate at the Center for Policy Research. Anil Kumar is a research associate at the Center for Policy Research. The research reported herein was performed pursuant to a grant from the U.S. Social Security Administration (SSA) to the Center for Retirement Research at Boston College (CRR). The opinions and conclusions are solely those of the authors and should not be construed as representing the opinions or policy of the SSA or any agency of the Federal Government or of the CRR. The authors would like to thank Dan Black, Chris Cunnin gham, Bill Gale, Erik Hurst, Brigitte Madrian, John Moran, and seminar participants at Syracuse University, University of Chicago, and University of Virginia for helpful discussions and comments.

(C) 2004, by Gary V. Engelhardt and Anil Kumar. All rights reserved. Short sections of text, not to exceed two paragraphs, may be quoted without explicit permission provided that full credit, including $\odot$ notice, is given to the source. 


\section{About the Center for Retirement Research}

The Center for Retirement Research at Boston College, part of a consortium that includes parallel centers at the University of Michigan and the National Bureau of Economic Research, was established in 1998 through a grant from the Social Security Administration. The goals of the Center are to promote research on retirement issues, to transmit new findings to the policy community and the public, to help train new scholars, and to broaden access to valuable data sources. Through these initiatives, the Center hopes to forge a strong link between the academic and policy communities around an issue of critical importance to the nation's future.

\section{Center for Retirement Research at Boston College}

550 Fulton Hall

140 Commonwealth Ave.

Chestnut Hill, MA 02467

phone: 617-552-1762 fax: 617-552-1750

e-mail: crr@bc.edu

http://www.bc.edu/crr

Affiliated Institutions:

American Enterprise Institute

The Brookings Institution

Massachusetts Institute of Technology

Syracuse University

Urban Institute 


\begin{abstract}
Employer matching of employee 401(k) contributions can provide a powerful incentive to save for retirement. We examine the effect of matching on 401(k) saving accounting for non-linearities in the intertemporal budget set. We use detailed administrative contribution, earnings, and pension plan data from the Health and Retirement Study and estimate that the elasticity of contributions with respect to matching is $0.15-0.27$ overall, with sixty percent of this effect on the participation margin and the remaining forty percent on the intensive margin. The estimated after-tax cross-price elasticity of $401(\mathrm{k})$ contributions with respect to IRA saving is -0.60 , which suggests $401(\mathrm{k}) \mathrm{s}$ and IRAs are substitutes in tax-deferred saving. We find no evidence of endogenous worker sorting based on the discount rate to plans that offer matching.
\end{abstract}




\section{Introduction}

As 401(k)s have come to dominate the pension landscape, researchers and policy makers have given increased attention to the impact of plan characteristics on retirement saving decisions. ${ }^{1}$ One important characteristic is whether and to what extent the employer matches employee contributions. A typical match might be 50 cents for each dollar of contribution, up to a maximum percentage of pay, say, 6 percent. Although much of the discussion by the popular press and policy makers presumes employer matching raises saving, there is actually strikingly little consensus among researchers. Some studies have found that increases in the match rate raise 401(k) saving (Papke and Poterba, 1995; Clark and Schieber, 1998). Others have found that it is not the match rate per se that matters, but whether the firm offers a match at all (Bassett, Fleming, and Rodrigues, 1998; Papke, 1995; Kusko, Poterba, and Wilcox, 1998). That is, providing a match raises $401(\mathrm{k})$ saving, but an increase in the level of the match rate (conditional on providing a match) does not. Finally, still other studies (Munnell, Sunden, and Taylor, 1998; and GAO, 1997) have suggested that, conditional on being eligible for a match, an increase in the match rate lowers $401(\mathrm{k})$ contributions, which, when interpreted in the context of a simple two-period model of saving, suggests that the income effect dominates the substitution effect from the higher rate of return matching provides. $^{2}$

A central shortcoming in this literature has been the failure to exploit the fact that employer matching based either on a multiple match-rate schedule or caps on the

\footnotetext{
1 This includes work on automatic enrollment (Madrian and Shea, 2000, Choi, Laibson, Madrian, and Metrick, 2001, 2002), investment in company stock (Poterba, 2003), portfolio choice and trading in 401(k) plans (Benartzi and Thaler, 2001; Agnew, Balduzzi, and Sunden, 2003).

2 Throughout the paper, we refer to $401(\mathrm{k})$ saving and $401(\mathrm{k})$ contributions synonymously as per period flows. In a multi-period model, this would suggest the income effect dominates the substitution and human wealth effects (Summers, 1981).
} 
generosity of the match induces kinks in the intertemporal budget constraint. As has been long recognized in the study of taxation on labor supply, reduced-form estimates of behavioral elasticities are biased and inconsistent unless these kinks are accounted for explicitly (Hausman, 1985; Moffitt, 1990). Indeed, the presence of kinks may reconcile some of the findings of previous studies. For example, the provision of a match may raise $401(\mathrm{k})$ saving if the substitution effect dominates, but variation in match rates may not matter if employees are bunched at kinks.

We make five important contributions. First, we lay out a theoretical model and specify a life-cycle consistent structural econometric specification based directly on the first-order conditions for 401(k) saving. Second, we circumvent difficulties with measurement error in $401(\mathrm{k})$ contributions and matching incentives that have plagued previous studies by using administrative data from three sources: contributions from W-2 earnings records provided by the Social Security Administration (SSA) and Internal Revenue Service (IRS); detailed matching formulas from pension Summary Plan Descriptions (SPD) provided by the employers of HRS respondents; and, a combination of covered earnings histories for 1951-1991 and W-2 earnings for 1980-1991 from SSA, pension SPDs, and pension benefit calculators to construct public and private pension entitlements and accruals. Our sample consists of 1,042 individuals in 1991 eligible for 401(k) plans in the Health and Retirement Study (HRS). Third, we account for kinks in the estimation using a variant of the differentiable budget set methodology of MaCurdy, Green, and Paarsch (1990) based on kernel regression Fourth, we estimate ad hoc reduced-form empirical models similar to past studies, and are able to replicate many of the puzzling findings from the previous literature in our data: the existence of a matching 
program raises $401(\mathrm{k})$ saving, but conditional on offering a match, higher match rates have no effect or lower contributions. In contrast, our structural instrumental variable Tobit specifications suggest that the uncompensated elasticity of 401(k) saving with respect to the match rate is $0.15-0.27$ overall, with sixty percent of this effect on the participation margin and forty percent on the intensive margin. We estimate little impact of income on contributions. The estimated elasticity of contributions with respect to the net hourly wage and the relative after-tax price of $401(\mathrm{k})$ versus IRA saving are 0.40 and -0.60 , respectively, the latter of which confirms the intuition that 401(k) and IRA saving are substitutes. Fifth, we test whether individuals with low discount rates work at firms with higher employer match rates (Ippolito, 1997), often used as a criticism of the quasiexperimental "eligibility experiment" approach to identifying 401(k) saving effects (Poterba, Venti, and Wise, 1994, 1995). We find no evidence of worker sorting based on discount rates.

The paper is organized as follows. Section II lays out the theoretical model that directly motivates the empirical work. Section III lays out the econometric framework and construction of the key variables. Section IV describes the data. Section V discusses the identification strategy. The empirical test for endogenous worker sorting is in section VI. Section VII discusses the estimation results. There is a brief conclusion.

\section{Theoretical Framework}

Previous studies, summarized in Table 1, have failed to exploit the fact that multiple-match rate schedules and caps on matching induce kinks in the intertemporal budget set. For example, Figure 1 shows the budget set in a simple two-period model of consumption typically used in undergraduate textbooks. Let $c_{1}$ and $c_{2}$ be consumption 
in periods 1 and 2, respectively, and $y_{1}$ be first-period earnings. For simplicity, assume a single marginal tax rate, $\theta$, in the first period, no taxes and earnings in the second period, 401(k)s are the only form of saving and contributions are tax-deductible. Assume the firm matches contributions at a fixed rate $m$ up to $q^{\text {match }}$ of contributions, and a limit on contributions, $q^{\max }$. Then, as shown in the figure, the budget constraint is $\overline{a k d b}$. From zero to $q^{\text {match }}$ contributions, the slope of the budget constraint is $-(1+m)(1+r) /(1-\theta)$, from $q^{\text {match }}$ to $q^{\max }$, the slope is $-(1+r) /(1-\theta)$, and beyond $q^{\max }$, the slope is zero. At $q^{\text {match }}$, there is a kink point, $k$. It is obvious from the figure that, in the absence of matching, the introduction of an uncapped match has standard substitution and income effects. $^{3}$ However, this may not occur if the match is capped. That is, compensated changes in the match rate, $m$, may not induce changes in $401(\mathrm{k})$ saving if individuals are bunched at the kink point, $k$, and standard income and substitution effects are not well defined. Instead, standard income and substitution effects on each budget segment are defined by the slopes given above and the virtual incomes, $y^{v_{1}}$ and $y^{v_{2}}$.

In addition, even though saving involves the substitution of resources across time, previous studies have not couched their analyses in formal models of intertemporal choice. This means that previous estimates cannot be interpreted as estimates of lifecycle-consistent uncompensated demands for 401(k) saving necessarily, because the empirical specifications may not be consistent with underlying utility maximization. So, while previous studies have been quite informative descriptive analyses, they say little

\footnotetext{
${ }^{3}$ In fact, if the match rate and tax rate are zero, the figure collapses to the standard undergraduate textbook figure, in which the slope is just $-(1+r)$.
} 
about how 401(k) saving may respond to prospective changes in employer matching or what the optimal match rate should be to achieve a target saving objective.

In contrast, we estimate econometric models of contributions that are consistent with life-cycle theory and incorporate non-linear budget sets explicitly. The budget sets individuals actually face are substantially more complicated than the one depicted in Figure 1 for a number of reasons. First, they may have multiple kinks due to variablerate matches. Second, there may be multiple kinks because there are multiple marginal tax rates and contributions are tax-deductible, so that making a contribution may change the marginal tax rate. Surprisingly, none of the previous studies have accounted for the effect of taxation on 401(k) saving. Third, 401(k) plan participants also can save through other vehicles, such as IRAs and non-tax-deferred financial asset saving. Finally, there may be goods other than consumption, such as leisure, that enter utility, and a change in the match rate may induce intratemporal substitution across goods.

To motivate the empirical work, we use a theoretical framework that incorporates these additional facets of behavior. Specifically, utility is derived from consumption, $C$, leisure, $l$, depends on a set of demographics, $Z$, and is weakly separable. The consumer lives from the beginning of working life, period 0 , until death in period $\mathrm{T}$. The lifetime is composed of two parts. From period $\tau+1$ to $T$, the consumer is retired and chooses consumption, $C$, to maximize the present value of utility. In retirement, no hours of labor are supplied to the market, so leisure equals the time endowment, $L^{l}$. From period 0 to $\tau$, the consumer works and chooses consumption, leisure, voluntary 401(k) contributions, $Q^{401 k}$, and IRA contributions, $Q^{I R A}$, respectively. Wealth is accumulated in five assets: $401(\mathrm{k})$ wealth, $W^{401 k}$, IRA wealth, $W^{I R A}$, non-401(k) pension wealth, 
$W^{P}$, non-401(k)-IRA-pension wealth, $W^{A}$, and the present value of Social Security benefits, $W^{S S}$, where total wealth is

$$
W^{T} \equiv W^{401 k}+W^{I R A}+W^{A}+W^{P}+W^{S S}
$$

Let $\psi\left(W_{\tau}^{T}\right)$ be the expected present value at period $\tau$ of utility for the second part of life, as viewed during the first part of life, and $\rho$ the rate of time preference. When working, the objective function is

$$
\max _{C_{t}, Q_{t}^{40 k}, Q_{t}^{I R A}, l_{t}} E_{t}\left[\sum_{t=0}^{\tau}(1+\rho)^{-t} U\left(C_{t}, l_{t} ; Z_{t}\right)+(1+\rho)^{-\tau} \psi\left(W_{\tau}^{T}\right)\right],
$$

and the components of wealth evolve as follows

$$
\begin{gathered}
W_{t}^{A}=\left(1+r_{t}\right) W_{t-1}^{A}+w_{t}\left(L^{l}-l_{t}\right)+B_{t}-C_{t}-Q_{t}^{401 k}-Q_{t}^{I R A}-T_{t}, \\
W_{t}^{401 k}=\left(1+r_{t}\right) W_{t-1}^{401 k}+\left(Q_{t}^{401 k}+M_{t}^{V}+R_{t}+M_{t}^{R}\right), \\
W_{t}^{I R A}=\left(1+r_{t}\right) W_{t-1}^{I R A}+Q_{t}^{I R A}, \\
W_{t}^{P}=\left(1+\alpha_{t}^{P}\right) W_{t-1}^{P},
\end{gathered}
$$

and

$$
W_{t}^{S S}=\left(1+\alpha_{t}^{S S}\right) W_{t-1}^{S S} .
$$

In (3), $r_{t}$ is the stochastic gross interest rate earned on assets between periods $t-1$ and $t$, and $E_{t}$ in (2) is the expectations operator conditional on the information set $\Omega_{t-1} \cdot{ }^{5} \quad B_{t}$ is

\footnotetext{
${ }^{4}$ Non-401(k) pensions consist of all defined benefit plans and defined contribution plans not governed by section $401(\mathrm{k})$ of the Internal Revenue Code. We do not explicitly consider the role of housing, which is subsumed into other wealth. Engen, Gale, and Scholz (1996), Poterba, Venti, and Wise (1996), Bernheim (2002), and Engelhardt (2001), among others, have discussed the potential interactions between housing and $401(\mathrm{k}) \mathrm{s}$.

5 We assume that all non-pension wealth earns the same gross rate of return. There is no other uncertainty in the model, and there are no bequests. The mean age in our sample below is 55. Carroll (1992), among others, has estimated that most lifetime income uncertainty has been resolved by this age, at which point households have transitioned from buffer stock to life-cycle savers. Hence, we did not feel income uncertainty was central to the households under study and did not model it. Uncertainty in the length of life
} 
other income, $w_{t}$ is the gross wage rate, and $w_{t}\left(L^{l}-l_{t}\right) \equiv y^{l}$ is labor earnings. In (6) and (7), the non-401(k) pension and Social Security accrual rates, $\alpha^{P}$ and $\alpha^{S S}$, respectively, are functions of age, earnings, and time. ${ }^{6}$

Some employers mandate $401(\mathrm{k})$ contributions. In addition, the firm may match those mandatory contributions (Cunningham and Engelhardt, 2002). Therefore, let $R$ be the employee's mandatory $401(\mathrm{k})$ contribution and $M^{R}$ be the employer's matching contribution in dollars on the employee's mandatory contribution. Define $M^{V}$ to be the employer's matching contribution in dollars on the employee's voluntary contribution.

The matching functions are

$$
M_{t}^{V}=M^{V}\left(Q_{t}^{401 k}, y_{t}^{l}, m_{t}^{V}\right)
$$

and

$$
M_{t}^{R}=M^{R}\left(R_{t}, y_{t}^{l}, m_{t}^{R}\right),
$$

respectively. Here, $m^{V}$ and $m^{R}$ are vectors of plan-specified match rates for voluntary and required 401(k) contributions, respectively.

In (3), $T$ is the sum of income and payroll tax liability. It is a function,

$$
T_{t}=f^{T}\left(\theta_{t}^{F}, \theta_{t}^{P} ; I_{t}^{F}, \min \left(y_{t}^{l}, L_{t}^{P}\right)\right)
$$

\footnotetext{
and bequests are potentially important for these households. Intended bequests will change the objective function in the second part of life and the terminal condition in period $T$. These will result in changes in the level of wealth brought into the second stage of life, but will not affect the derivation of the first-order conditions directly for the first-stage of life given below, and, hence, do not affect our empirical specifications. In addition, we do not address directly 401(k)-induced retirement (Feldstein, 1974). However, our sample includes individuals in 401(k)-eligible jobs in 1991, some of whom were retired as of the first HRS interview, so we do not exclude retirees from our empirical analysis. Friedberg and Webb (2003) have examined the impact of the spread of defined contribution and 401(k) plans on retirement.

${ }^{6}$ For defined contribution plans, the accrual represents the sum of the employer's per period contribution to the account and the capital income on the account balance for that period. For defined benefit plans, the accrual is typically a complicated function of age, earnings, and years of service.
} 
of a vector of statutory marginal income tax rates, $\theta^{F}$, and FICA and Medicare payroll tax rates, $\theta^{P} .^{7}$ Federal taxable income is

$$
I_{t}^{F}=\left[\left(y_{t}^{l}-Q_{t}^{401 k}-R_{t}\right)+r_{t} W_{t-1}^{A}-\zeta_{t} Q_{t}^{I R A}\right]-X_{t}-D_{t}
$$

where $X$ is personal exemptions and $D$ is deductions. The factor $\zeta$ is the fraction of

IRA contributions that is federally tax-deductible,

$$
\zeta_{t}=\zeta\left(y_{t}^{l}-Q_{t}^{401 k}-R_{t}+r_{t} W_{t-1}^{A}\right)
$$

IRA deductibility depends on adjusted gross income (AGI), and itself is a function of 401(k) contributions because contributions are excluded from AGI. ${ }^{8} L^{P}$ is a vector of covered-earnings caps for payroll taxes.

Sum (3)-(7) to yield the equation of motion for total wealth,

$$
\begin{aligned}
W_{t}^{T}=(1 & \left.+r_{t}\right)\left(W_{t-1}^{A}+W_{t-1}^{401 k}+W_{t-1}^{I R A}\right)+\left(1+\alpha_{t}^{P}\right) W_{t-1}^{P}+\left(1+\alpha_{t}^{S S}\right) W_{t-1}^{S S}+\left(M_{t}^{V}+R_{t}+M_{t}^{R}\right) \\
& +w_{t}\left(L^{l}-l_{t}\right)+B_{t}-C_{t}-T_{t} .
\end{aligned}
$$

Let $\lambda_{t}$ be the multiplier on this constraint. In addition, we allow for a liquidity constraint, $W_{t}^{A} \geq \xi_{t}$, where $\xi \geq 0$ is an exogenous level of wealth, so that expenditure on consumption, leisure, and tax-deferred saving must be less than or equal to after-tax cash on hand (net of $\xi$ ):

\footnotetext{
7 For simplicity in exposition, we have suppressed notation for state income taxes. However, we include them in the empirical analysis below.

8 The term in parentheses within the square brackets in (11) is income for federal tax purposes reported on Form W-2, and the term in square brackets is AGI. Prior to the Tax Reform Act of 1986 (TRA86), IRA contributions were fully tax-deductible up to the limit of $\$ 2,000$ for single individuals and $\$ 2,250$ for married couples. TRA86 limited the deductibility of contributions. For single individuals, contributions remained fully deductible if adjusted gross income was less than $\$ 25,000$, were linearly phased out for incomes between $\$ 25,000$ and $\$ 35,000$, and not deductible for incomes above $\$ 35,000$. For married couples, contributions remained fully deductible if adjusted gross income was less than $\$ 40,000$, were linearly phased out for incomes between $\$ 40,000$ and $\$ 50,000$, and not deductible for incomes above $\$ 50,000$. Therefore, $\zeta$ varies according to a non-linear interaction of income, defined as $\omega_{t}\left(L^{l}-l_{t}\right)-Q_{t}^{401 k}-R_{t}+r_{t} W_{t-1}^{A}$ and marital status.
} 


$$
C_{t}+\omega_{t} l_{t}+Q_{t}^{401 k}+Q_{t}^{I R A} \leq-\xi_{t}+\left(1+r_{t}\right) W_{t-1}^{A}+w_{t} L^{l}+B_{t}-T_{t}
$$

Let $\mu_{t}$ be the associated multiplier. ${ }^{9}$ In addition, there are minimum and maximum contribution constraints on $401(\mathrm{k}) \mathrm{s}$ and IRAs with multipliers in square brackets, respectively,

$$
\begin{array}{ll}
Q_{t}^{401 k} \geq 0, & {\left[\eta_{t}^{0}\right]} \\
Q_{t}^{401 k} \leq L_{t}^{401 k}, & {\left[\eta_{t}^{L}\right]} \\
Q_{t}^{I R A} \geq 0, & {\left[\mathrm{v}_{t}^{0}\right]}
\end{array}
$$

and

$$
Q_{t}^{I R A} \leq L_{t}^{I R A}
$$

The terms $L^{401 k}$ and $L^{I R A}$ are the upper limits on 401(k) and IRA contributions, respectively. $\quad L^{I R A}$ is governed by federal law and depends on marital status and pension coverage. $^{10} L^{401 k}$ is governed by the employer's plan, but may not exceed the federal statutory maximum under ERISA.

The first-order conditions when working are

$$
\begin{gathered}
U_{C}\left(C_{t}, l_{t} ; Z_{t}\right) \cdot(1+\rho)^{-t}=\lambda_{t}+\mu_{t}, \\
\lambda_{t} \frac{1+M_{Q^{401 k_{t}}}^{V}}{1-T_{I t}\left(1-\zeta_{y^{l} t} Q_{t}^{I R A}\right)}+\frac{\eta_{t}^{0}-\eta_{t}^{L}}{1-T_{I t}\left(1-\zeta_{y^{l} t} Q_{t}^{I R A}\right)}=\lambda_{t}+\mu_{t},
\end{gathered}
$$

\footnotetext{
${ }^{9} \mathrm{We}$ assume that consumers prior to retirement neither have access to nor may borrow against IRA, 401(k), non-401(k) pension, and Social Security assets. Therefore, the only technology for transferring resources across periods when working is through non-401(k)-IRA financial assets. This assumption simplifies the theoretical analysis. We do not model pre-retirement withdrawals from 401(k) and IRA plans (Engelhardt 2002). In terms of the empirical analysis, the HRS surveyed individuals who were 51-61 in 1992. For many of these individuals, the statutory limitations and penalties on pre-retirement IRA and lump-sum distributions do not apply because they satisfy various age requirements in the federal law. In the empirical analysis below, we control for age flexibly with a quartic function and whether the 401(k) plan allows hardship withdrawals and borrowing. We do not model leisure as bounded by zero and the leisure endowment because $401(\mathrm{k})$ matching contributions are available only to those who work.

${ }^{10}$ These limits apply to the sum of deductible and non-deductible IRA contributions.
} 


$$
\lambda_{t} \frac{1}{1-T_{I t} \zeta_{t}}+\frac{v_{t}^{0}-v_{t}^{L}}{1-T_{I t} \zeta_{t}}=\lambda_{t}+\mu_{t}
$$

and,

$$
\begin{aligned}
U_{l}\left(C_{t}, l_{t} ; Z_{t}\right) \cdot(1+\rho)^{-t} & =\lambda_{t}\left[w_{t}\left(\alpha_{y^{\prime} t}^{P} W_{t-1}^{P}+\alpha_{y^{\prime} t}^{S S} W_{t-1}^{S S}+M_{y^{\prime} t}^{V}+R_{y^{\prime} t}+M_{y^{\prime} t}^{R}\right)\right] \\
& +\left(\lambda_{t}+\mu_{t}\right)\left[w_{t}\left(1-T_{I^{\prime}}\left(1-R_{y^{\prime} t}-\zeta_{y^{\prime} t} Q_{t}^{I R A}\right)\right)\right]
\end{aligned}
$$

Note that subscripts indicate a partial derivative (other than $t$, which denotes time); for example, $T_{I}$ is simply the marginal tax rate. Equation (19) is standard. Equations (20) and (21) are the first-order conditions for 401(k) and IRA saving, respectively. $M_{Q^{40 k}}^{V}$ is the marginal employer match rate for an additional dollar of $401(\mathrm{k})$ contribution, $T_{I}$ is the marginal tax rate, and $\zeta_{y^{l}}$ is the change in the fraction of an IRA contribution that is deductible for an additional dollar of AGI. Combine the two equations to yield

$$
\lambda_{t} \frac{1+M_{Q^{401 k_{t}}}^{V}}{1-T_{I t}\left(1-\zeta_{y^{\prime} t} Q_{t}^{I R A}\right)}+\frac{\eta_{t}^{0}-\eta_{t}^{L}}{1-T_{I t}\left(1-\zeta_{y^{\prime} t} Q_{t}^{I R A}\right)}=\lambda_{t} \frac{1}{1-T_{I t} \zeta}+\frac{v_{t}^{0}-v_{t}^{L}}{1-T_{I t} \zeta}
$$

an arbitrage condition that says that the marginal value of an additional dollar of 401(k) saving must be just equal to that of a dollar of IRA saving at the optimum. ${ }^{12}$ Equation (22) is the first-order condition with respect to leisure. It is substantially more complicated than in most models of labor supply because of the presence of public and private pensions. ${ }^{13}$

\footnotetext{
${ }^{11}$ Because we will estimate the demand for $401(\mathrm{k})$ contributions for workers on 401(k)-eligible jobs, we naturally limit our discussion to the first part of life. The first-order conditions for the full model including the second part of life are available from the authors.

12 This can be seen more easily in the simplifying case of interior solutions for $401(\mathrm{k})$ and IRA saving, $\eta^{0}=0, \eta^{L}=0, v^{0}=0$, and $v^{L}=0$, where (23) reduces to $1+M_{Q^{40 \text { v }}}^{V} / 1-T_{I}\left(1-\zeta_{y^{l}} Q^{I R A}\right)=1 / 1-T_{I} \zeta$.

${ }^{13}$ For example, if there were no pensions, and IRA contributions were not deductible, (22) would reduce to
} 


\section{Econometric Framework}

To derive the econometric model for the structural estimation, let $i$ and $j$ index individuals and 401(k) plans, respectively. ${ }^{14}$ Multiply both sides of equation (23) by $1-T_{I i t}\left(1-\zeta_{y^{l}{ }_{i t}} Q_{i t}^{I R A}\right)$, and denote

$$
p_{i j t}^{m}=1+M_{Q^{40 k} i j t}^{V}
$$

as the match price,

$$
p_{i t}^{\tau}=\frac{1-T_{I i t}\left(1-\zeta_{y^{\prime} i t} Q_{i t}^{I R A}\right)}{1-T_{I i t} \zeta_{i t}}
$$

as the relative after-tax price of $401(\mathrm{k})$ to IRA saving, and then rearrange (23) to yield

$$
\eta_{i j t}^{L}-\eta_{i j t}^{0}=\lambda_{i t}\left(p_{i j t}^{m}-p_{i t}^{\tau}\right)+p_{i t}^{\tau}\left(v_{i t}^{L}-v_{i t}^{0}\right)
$$

The left-hand side of (26) represents a latent variable: when $\eta^{L}-\eta^{0}>0$, desired $401(\mathrm{k})$ contributions, $Q^{401 k^{*}}$, exceed the plan limit, $L^{401 k}$, and observed contributions, $Q^{401 k}$, equal the limit; when $\eta^{L}-\eta^{0}=0$, observed 401(k) contributions equal desired

$U_{l}\left(C_{t}, l_{t} ; Z_{t}\right) \cdot(1+\rho)^{-t}=\left(\lambda_{t}+\mu_{t}\right)\left[w_{t}\left(1-T_{I t}\right)\right]$, in which hours of labor supplied would be a function of the net wage, and (19) and (22) would combine for the standard intratemporal marginal substitution condition,

$$
\frac{U_{C}\left(C_{t}, l_{t} ; Z_{t}\right)}{U_{l}\left(C_{t}, l_{t} ; Z_{t}\right)}=\frac{1}{w_{t}\left(1-T_{I t}\right)},
$$

where consumption is the numeraire. In (22), the additional factor $1-R_{y^{\prime} t}-\zeta_{y^{\prime} t} Q_{t}^{I R A}$ multiplying the marginal tax rate occurs because additional hours raise earnings and AGI, which change the employee's mandatory pension contribution (which is deductible) and the deductibility of IRA contributions, respectively. The introduction of public and traditional private pensions adds an additional term to (22), $\lambda_{t} w_{t}\left(\alpha_{y^{\prime} t}^{P} W_{t-1}^{P}+\alpha_{y^{\prime} t}^{S S} W_{t-1}^{S S}+M_{y^{\prime} t}^{V}+R_{y^{l} t}+M_{y^{\prime} t}^{R}\right)$, that represents the effect of additional earnings (through greater hours) on non-401(k) pension accruals, Social Security accruals, 401(k) employer matching of voluntary contributions, mandatory employee contributions, and employer matching of mandatory employee contributions. For example, if the employer contributes five percent of earnings to a pension plan, then the opportunity cost of leisure will depend not just on the net wage, but also the lost employer contribution, the value of which depends on the marginal utility of wealth, $\lambda$.

${ }^{14}$ The data we describe below are cross-sectional for 1991. We maintain the time subscript to distinguish the timing of the lagged variables we use to construct the instruments. 
contributions; and, finally, when $\eta^{L}-\eta^{0}<0$, desired contributions are less than or equal to zero and observed contributions equal zero. We use a two-stage budgeting measure of "full income," so that the first term on the right-hand side of (26) is product of the marginal utility of full income, $\lambda$, and the difference between the match and relative after-tax price of contributing, $\Delta p \equiv p^{m}-p^{\tau}$. Let $V(\omega, y ; \delta)$ denote the intratemporal indirect utility function, in which $\delta$ is a vector of utility function parameters and $\omega$ is the marginal price of leisure,

$$
\omega_{i j t}=w_{i t}\left[1-T_{I i t}\left(1-R_{y^{l} i j t}-\zeta_{y^{l} i t} Q_{i t}^{I R A}\right)+\left(\alpha_{y^{l} i j t}^{P} W_{i j t-1}^{P}+\alpha_{y^{l} i t}^{S S} W_{i t-1}^{S S}+M_{y^{l} i j t}^{V}+R_{y^{l} i j t}+M_{y^{\prime} i j t}^{R}\right)\right]
$$

Because of the non-linear structure of matching and marginal tax rates, the prices in (26) change depending upon the budget set segment (either because the marginal match rate or tax rate changes). Hence, full income is measured as "virtual" full income, $y^{v}$, according to the respective budget segment, with $T^{v}$ the associated tax liability. From (3)-(7) and (13), $y^{v}$ is

$$
y_{i j t}^{v} \equiv C_{i t}+w_{i t} l_{i t}
$$

which, upon substituting (4)-(7) into (13), can be expressed equivalently as

$$
y_{i j t}^{v} \equiv-\Delta W_{i t}^{A}+r_{t} W_{i t-1}^{A}+w_{i t} L^{l}+B_{i t}-Q_{i j t}^{401 k}-Q_{i t}^{I R A}-T_{i j t}^{v},
$$

and includes the market value of the leisure endowment. ${ }^{15}$ The second term of the righthand side of (26), $v^{L}-v^{0}$, is zero when IRA saving is at an interior solution, positive

\footnotetext{
15 The tax liability associated with virtual full income, $T^{v}$, varies by plan because the employer match rate enters the implicit tax rate. The necessary condition for two-stage budgeting is that utility be weakly separable (Gorman, 1959). Our model in (2) assumes strongly intertemporal and weakly intratemporal separable preferences. The solution to the two-stage budgeting problem is recursive. In the first step, the individual chooses consumption and leisure to maximize intratemporal utility subject to the budget constraint that consumption and the market value of leisure equal full income. In the second step, the time
} 
when constrained by the upper IRA limit, and negative when at the lower IRA limit (of zero). Therefore, express the second term as

$$
\kappa_{i t} \equiv p_{i t}^{\tau}\left(D_{i t}^{L^{I R A}}-D_{i t}^{0}\right)
$$

where $D^{L^{I R A}}$ is a dummy variable that is one if IRA contributions are at the upper limit and zero otherwise, and $D^{0}$ is a dummy variable that is one if IRA contributions are zero and zero otherwise. Substitute the marginal utility of virtual full income, $V_{y}\left(\omega, y^{v} ; \delta\right)$, into (26), let $u$ be an additive term that captures heterogeneity in contribution behavior, then re-write (26) as

$$
Q_{i j t}^{401 k^{*}}=V_{y}\left(\omega_{i t}, y_{i t}^{v} ; \delta\right) \Delta p_{i j t}+\gamma \kappa_{i t}+u_{i j t}
$$

Let $u$ be composed of two components,

$$
u_{i j t}=\left(\alpha x_{1 i t}+\varepsilon_{i t}\right)+\left(\psi x_{2 j}+v_{j}\right) \text {, }
$$

where $x_{1}$ is a vector of exogenous observable individual characteristics, $\varepsilon$ is a random variable, $\varepsilon \sim N\left(0, \sigma_{\varepsilon}^{2}\right), x_{2}$ is a vector of exogenous observable plan characteristics, and $v$ is a random plan effect, $v \sim N\left(0, \sigma_{v}^{2}\right)$.

The model in (31)-(32) can be estimated by maximum likelihood once the functional form for the marginal utility of virtual full income, $V_{y}\left(\omega, y^{v} ; \delta\right)$, is specified. To keep the index function in the Tobit specification linear in parameters, we employ functional forms for $V_{y}$ that are linear in utility parameters. In the baseline model,

$$
V_{y}=\delta_{1}+\delta_{2} \omega+2 \delta_{3} y
$$

so that (31) becomes

path of $W^{A}, 401(\mathrm{k})$, and IRA saving are chosen to maximize the discounted indirect utility subject to the lifetime budget constraint, liquidity constraint, and the control constraints on 401(k) and IRA saving. 


$$
Q_{i j t}^{401 k^{*}}=\beta_{1} \Delta p_{i j t}+\beta_{2} \omega_{i t} \Delta p_{i j t}+\beta_{3} y_{i t}^{v} \Delta p_{i j t}+\gamma \kappa_{i t}+\alpha x_{1 i t}+\psi x_{2 j}+\varepsilon_{i t}+v_{j},
$$

where $\beta_{1}=\delta_{1}, \beta_{2}=\delta_{2}$, and $\beta_{3}=2 \delta_{3}$. Theory imposes no restrictions on the form of $V_{y}$ other than it must be non-negative, and, thus, is agnostic on the signs of $\beta_{2}$ and $\beta_{3}{ }^{16}$ If matching raises contributions, then the null hypothesis $\beta_{1}=\beta_{2}=\beta_{3}=0$ should be rejected, and the estimated elasticity of contributions to matching should be positive. In addition, the first-order conditions indicate that $401(\mathrm{k})$ and IRA saving are substitutes. If so, then the null hypothesis $\beta_{1}=\beta_{2}=\beta_{3}=\gamma=0$ should be rejected, and the estimated elasticity of the relative after-tax price of $401(\mathrm{k})$ versus IRA saving should be negative. Finally, the estimated marginal utility of income should be non-negative. We also estimate models in which the marginal utility of income is quadratic,

$$
V_{y}=\delta_{1}+\delta_{2} \omega+2 \delta_{3} y+2 \delta_{4} \omega y+3 \delta_{5} y^{2}
$$

and logarithmic,

$$
V_{y}=\delta_{1}+\delta_{2} \ln \omega+\delta_{3} \ln y
$$

respectively.

\section{Data and Measurement}

Previous research on nationally representative individual-level survey data (Table 1), such as the Current Population Studies (CPS) and Surveys of Consumer Finances

\footnotetext{
16 Specifically, the underlying indirect utility function, $V$, must be monotonic, non-decreasing in income, non-increasing in prices, convex in prices, and homogeneous of degree zero. These conditions do not dictate the sign of $V_{y y}$, the curvature of marginal utility of income, which is the sign of $\delta_{3}$ and $\beta_{3}$. While it may be the case that in combination, the properties of non-decreasing in income, non-increasing in prices and convexity in prices may limit feasible parameter values, theory has little specific to say about the sign of $V_{y \omega}$, too, which is the sign of $\delta_{2}$ and $\beta_{2}$. Finally, we note that the sign of $\beta_{3}>0$ cannot be interpreted as evidence that consumption or leisure are inferior goods. In particular, by differentiating Roy's Identity with respect to income, whether $V_{y y}$ will be negative if the good is normal depends on the sign of $V_{\omega y}$, which is not dictated by theory.
} 
(SCF), that are plagued by two important sources of measurement error. First, even though the researcher must know the entire match schedule for a plan to account for the individual's full opportunity set, as well as whether the match is discretionary or through profit-sharing, the typical survey respondent has great difficulty in accurately conveying even relatively simple pension provisions to interviewers, no less detailed matching schedules. ${ }^{17}$ Second, self-reported contribution data also suffer from substantial reporting error. $^{18}$ Finally, the data required to model saving are quite extensive: contributions, components of household (including spousal) income, assets, debts, demographics, marginal tax rates, spousal pension coverage, and expected entitlements from Social Security and traditional pensions, which require lifetime and job earnings histories, respectively. Previous studies have not had all of these data. ${ }^{19}$

We overcome these problems by using remarkably detailed data from the Health and Retirement Study (HRS), a nationally representative random sample of 51-61 year olds and their spouses (regardless of age) in 1992. The HRS asked detailed questions about household income, tax information, wealth, demographic s, spousal characteristics, employment, and pensions. A unique feature of these data is that the HRS collected

\footnotetext{
${ }^{17}$ See Mitchell (1988), Starr-McCluer and Sunden (1999), Johnson, Sambamoorthi, and Crystal (2000), Gustman and Steinmeier (1999), Rohwedder 2003a, 2003b), and Engelhardt 2001) for evidence on measurement error in pension data.

${ }^{18}$ For example, some plans mandate employee contributions as a condition of eligibility (Cunningham and Engelhardt, 2002). Surveys like the CPS and SCF do not distinguish between mandated and voluntary contributions, so that voluntary contributions are measured with error. Overall, there is likely substantial measurement error in survey data.

${ }^{19}$ Studies that instead have used detailed pension plan descriptions and employer personnel records have circumvented these reporting error issues and yielded very useful insights, but at the cost of relatively little or no knowledge about other factors that affect the worker's 401(k) saving decision, such as total household income, wealth, and spousal characteristics. (Clark and Schieber, 1998; Kusko, Poterba, and Wilcox, 1998). In addition, these studies have focused on a limited set of firms that are not nationally representative. The other studies in Table 1 used firm-level data from Form 5500 (Papke, 1995; General Accounting Office, 1997), which have no information on individual employees. Joulfaian and Richardson (2001) used W-2 data on contributions, but lacked detailed data on wealth, family characteristics, and pension plans.
} 
Summary Plan Descriptions (SPDs), which are legal descriptions of pensions written in plain English, from employers of HRS respondents. These descriptions allow us to sidestep the problems with measurement error outlined above, and, instead, measure the exact incentives to contribute due to the employer match by using the matching formulas given in the SPD. In addition, the HRS asked respondents' permission to link their survey responses to administrative earnings data from SSA and IRS. These data include covered earnings histories from 1951-1991 and W-2 earnings records for jobs held from 1980-1991, and were made available to us under a restricted-access confidential data agreement with the SSA and IRS, administered by the University of Michigan. In particular, the W-2's provide administrative data on earnings and 401(k) contributions (Cunningham and Engelhardt, 2002). Unlike the contributions data used in previous studies, these data are not subject to measurement error, as they are the employer's official report to the government on annual earnings and elective deferrals. When used with Social Security and pension benefit calculators, the data allow for the calculation of public and private pension entitlements. Overall, we have a comprehensive description of the household's financial situation and a significantly richer data source than previous studies.

Tables 2-4 illustrate the variation in matching provisions for $401(\mathrm{k})$ plans in the HRS. The tabulations were based on the 658 HRS defined contribution plans that allow for voluntary pre-tax employee contributions, of which 368 (or 52 percent) offer matching. Column 1 of Table 2 breaks down the 368 plans by the type of matching: seventy-three percent have fixed-rate matching; the remainder is divided almost 
exclusively between variable-rate and profit-sharing matching. ${ }^{20}$ The remaining category is discretionary matching. Because the extent of matching is not always known in advance to employees making deferral decisions in profit-sharing and discretionary plans, we focused on plans with fixed- and variable-rate matching in our empirical analysis.

We used a sample of 1042 individuals from the HRS who were employed in 1991, eligible for a 401(k), whose employer provided a SPD for the plan, and who had linked administrative W-2 and Social Security earnings data. The earnings and deferral data refer to calendar year $1991 .^{21}$ These individuals were associated with 387 plans, which implies that some plans have more than one individual in the sample. This allows us to estimate models that allow for a plan random effect, as indicated in (33). Column 2 of Table 2 shows that fifty-four percent (i.e., 209) plans in our analysis sample offered matching contributions. Among these, eighty percent had fixed-rate matching. Of the 1042 individuals, 372 were associated with plans that offered matching.

Many plans limit the amount of the match. These caps are usually expressed as a percent of pay in the SPD, but also can be a percent of contributions, and even a fixed dollar amount. Table 3 shows the distribution of matching caps in the analysis sample, expressed as a percent of annual pay. About 19 percent of these plans had caps on

\footnotetext{
${ }^{20}$ Seventeen percent of plans offered variable-rate matching. Nine percent of plans made matches through a profit-sharing mechanism. Variable-rate matching occurs when the employer chooses to match different portions of contributions at different rates. For example, the employer might match the first $\$ 500$ of contributions at 75 cents-per-dollar, and any the portion of contributions above $\$ 500$ at 25 cents-per-dollar. With profit-sharing matching, the employer does not commit to a set schedule of matching contributions, but instead periodically (e.g., annually) considers whether and how much to match employee contributions based on some measure of firm performance clearly indicated in the SPD. As a group, fixed-rate, variablerate, and profit-sharing-based matches are technically non-discretionary arrangements (though, obviously, profit-sharing allows for much "discretion" on the part of employers in matching employee contributions). Under discretionary matching the employer decides whether and how much to match, and there is no formal arrangement. Only one percent of plans utilized this arrangement.

${ }^{21}$ Some of the individuals in the sample worked in 1991 but were retired at the time of the first interview in 1992. Exclusion of these individuals had no impact on our estimation results.
} 
employer matching that were less than four percent of pay. The median cap was 6 percent of pay, but 15 percent of plans had higher caps. Plans also vary according to the match rate. Table 4 shows the distribution of "first-dollar" match rates in the analysis sample. $^{22}$ Columns 1 and 2 indicate that these match rates were clustered at 25, 50, and 100 percent, where the median match rate was 50 percent. However, 27 percent of the plans offered matches of 100 percent, and three plans offered match rates of 200 percent.

We used a variant of the differentiable budget set methodology of MaCurdy, Green, and Paarsch (1990) to calculate $p^{m}, p^{\tau}$, and $y^{v}$ for each individual in the sample. Specifically, we smoothed the kinks in the budget set non-parametrically using kernel regression of the implicit tax rate in (23) on AGI over the legally allowable range of $401(\mathrm{k})$ contributions of 0 to $\$ 9500$ using a second-order Gaussian kernel with a bandwidth based on Silverman's rule of thumb. ${ }^{23}$ This regression was done on an individual-by-individual basis, so that the smoothing is individual-budget-set specific. Integration of the estimated tax function yielded the tax liability, $T^{v}$, used to calculate virtual full income, $y^{v}$.

\section{Identification Strategy}

Unfortunately, $\omega, y^{v}, \Delta p$, and $\kappa$ in (33) all have components based on choice variables, and, therefore, are endogenous. Observed $\Delta p$ and $\kappa$ are endogenous because observed marginal match and tax rates depend upon 401(k) and IRA contributions. This

\footnotetext{
${ }^{22}$ Technically, first-dollar match rates are the rate at which the employer matches the first dollar of deferral by the employee. In plans with fixed-rate matching, this is the match rate, whereas for variable- rate plans, this is the first, and, almost always, the most generous match rate in the schedule.

23 MaCurdy, Green, and Paarsch (1990) used a cubic polynomial. We also smoothed using cubic polynomial and fractional polynomial regression and, overall, the results from the three methods were qualitatively similar, but the kernel regression gave a better fit to the budget sets. In the rare cases on nonconvexity in the budget set, we followed the labor supply literature and used the convex hull of the budget set.
} 
is transmitted to observed $y^{v}$ through the calculation of the observed tax liability, $T^{v}$, in the smoothing process. In addition, the market value of the leisure endowment, a component of $y^{v}$, is based on the gross wage, $w$, which is potentially endogenous, if, for example, individuals with high tastes for saving earn higher wages. ${ }^{24}$ To account for endogeneity, we estimated the parameters in (33) using the Tobit instrumental variable estimator of Newey (1986). The appendix gives a detailed description of the construction of the instrument set, but we highlight our methods here briefly.

There were three important considerations in constructing the instrument for $\Delta p$. First, we assumed rational expectations and based instruments on the information set $\Omega_{t-1}$. Because $t$ is 1991, we used information from $t-2$ (or 1989). Second, because the observed marginal match and tax rates depend upon 401(k) and IRA contributions, we formed the instrument for $\Delta p$ based on "first-dollar" measures, i.e., the employer match on the first dollar contributed and the marginal tax rate at which it is deductible (which equals the tax rate on the last dollar of earnings). Third, to minimize dependence on individual-specific income and family size that might be correlated with unobserved heterogeneity in saving behavior, we calculated the first-dollar rates for a synthetic individual of each marital status assumed to have no capital income, no children, under age 65 , and taking the standard deduction, where we treated marital status as exogenous. Let the subscript $\bullet$ denote a synthetic measure. Then we divided individuals into cells based on exogenous demographic characteristics, calculated the cell mean gross hourly

\footnotetext{
${ }^{24}$ We treat the gross wage for the individual eligible for the $401(\mathrm{k})$ as potentially endogenous. For married couples, however, we follow the labor supply literature and take the spouse's earnings as exogenous and include them in the non-capital, unearned income term, $B$, that appears in full income. Naturally, we recognize that one potential response to changes in the generosity of employer matching is to change spousal labor supply, but addressing that explicitly is beyond the scope of this paper.
} 
wage rate, $\bar{w}_{\bullet-2}$, and multiplied that by 2,000 annual hours, $\bar{H}$, to generate a synthetic labor earnings measure for the individual. Let superscripts $z$ and 0 denote an instrument and a first-dollar measure, respectively. Then the instrument for $\Delta p$ is

$$
\Delta p_{\bullet_{j t-2}}^{z} \equiv 1+M_{Q^{40 \bullet_{\bullet}} j}^{V 0}-\frac{1-T_{I \bullet t-2}^{0}\left(1-\zeta_{y^{\prime} \bullet_{t-2}}^{0} \bar{Q}^{I R A}\right)}{1-T_{I \bullet_{-}-2}^{0} \zeta_{\bullet_{t-2}}^{0}}
$$

where $\bar{Q}^{I R A}$ was set to fifty dollars for all individuals. The first-dollar match and tax rates were smoothed using kernel regression as described above.

There are two primary sources of variation in the instrument. First, the instrument varies by plan, $j$. That is, we assume that the variation in matching schedules across plans is exogenous conditional on the other explanatory variables in the model, $x_{1}$ and $x_{2}$. Second, it varies across synthetic individuals because the tax function is non-linear in income and marital status. One potential concern is that this variation might not be exogenous if, say, the true $401(\mathrm{k})$ demand is non-linear in income, so that the nonlinearity in the tax function simply picks up the impact of omitted non-linear terms. This is substantially mitigated by two factors. First, the tax function for the endogenous variable, $\Delta p$, is based on the tax system in 1991, but the tax function for the instrument, $\Delta p_{\cdot j t-2}^{z}$, is different because it based on the tax system in 1989. Figure 2 plots the federal marginal tax rate by real AGI (in 1991 dollars) for a single individual under 65 in 1989 and 1991. For individuals with AGI below $\$ 50,000$, the functions are essentially the same, but differ for those above this level. Specifically, above this income level in 1989, the marginal tax rate increased from 28 to 33 percent due to the phase-out of the personal exemption. However, the Budget Act of 1990 raised the top marginal tax rate to 31 percent and changed the phase-out of the personal exemption. Therefore, the non- 
linearity in the instrument's tax function differs from that for the endogenous regressor due to the tax law change, which we take as exogenous to the individual. ${ }^{25}$ Second, as we discuss below, we estimated the specification in (34) with non-linear terms in income and interactions of income with the net wage in (35)-(36) and the results did not differ.

The instruments for $y^{v}$ and $\omega$ are $\widetilde{B}$, exogenous other income, and

$$
\begin{aligned}
\omega_{i j t-2}^{z}= & \bar{w}_{\bullet t-2}\left[1-T_{I i t-2}^{0}\left(1-R_{y^{\prime} \cdot j t}-\zeta_{y^{\prime} i t-2}^{0} \bar{Q}^{I R A}\right)\right. \\
& \left.+\left(\alpha_{y^{\prime} \cdot j t}^{P} W_{\bullet^{\prime} t-1}^{P}+\alpha_{y^{\prime} \bullet t}^{S S} W_{\bullet^{\prime}-1}^{S S}+M_{y^{\prime} \cdot j t}+R_{y^{\prime} \bullet j t}+M_{y^{\prime} \cdot j t}^{R}\right)\right]
\end{aligned}
$$

respectively, where, $T_{I}$ in (38) includes the payroll tax. For the private and public pension components in (38), we divided individuals into cells based on exogenous demographic characteristics and used the Social Security covered earnings from 19511991 and the W-2 earnings records from 1980-1991 to calculate earnings histories for a synthetic cell individual. These synthetic earnings histories were input as follows: into the University of Michigan's Pension Estimation Program to calculate pension wealth, $W^{P}$, accrual, $\alpha^{P}$, and change in accrual for additional earnings, $\alpha_{y^{\prime}}^{P}$, for individuals with defined benefit plans; into the $H R S D C / 401(k)$ Calculator we developed to calculate pension wealth, $W^{P}$, accrual, $\alpha^{P}$, and the effect of additional earnings on accrual, $\alpha_{y^{\prime}}^{P}$, employer match on voluntary contributions, $M_{y^{\prime}}$, required $401(\mathrm{k})$ contributions, $R_{y^{\prime}}$, and employer match on required contributions, $M_{y^{\prime}}^{R}$, respectively, for individuals with

\footnotetext{
${ }^{25}$ In theory, one could use state-level variation in state marginal income tax rates in the instrument. Unfortunately, the Memorandum of Understanding between the Social Security Administration and the University of Michigan concerning he use of restricted-access HRS data prevents the merging of any information based on state of residence to the Social Security covered earnings and W-2 earnings files used in this analysis, so that it is not possible to construct the instruments in this manner. However, we did add to the total tax liability, $T^{v}$, a weighted average state tax liability for the individual's Census division of residence, calculated assuming hypothetical residence in each state in the division, weighted by that state's share of the division adult population in the individual's income group.
} 
defined contribution plans; and, the Social Security benefit calculator developed by Coile and Gruber (2000) to calculate Social Security wealth, $W^{S S}$, accrual, $\alpha^{S S}$, and change in accrual for additional earnings, $\alpha_{y^{l}}^{S S} \cdot{ }^{26}$

Finally, to make the instrument for $\kappa$, note that if $\zeta=0$ (i.e., IRA contributions are not deductible), then the first-order condition (21) reduces to

$$
v_{t}^{L}-v_{t}^{0}=-\mu_{t}
$$

so that if the individual is liquidity constrained $\left(\mu_{t}>0\right)$, then $v_{t}^{0}>0$. Therefore, we used

$$
p_{\bullet j t-2}^{\tau z} \equiv \frac{1-T_{I \bullet t-2}^{0}\left(1-\zeta_{y^{\bullet} t-2}^{0} \bar{Q}^{I R A}\right)}{1-T_{I \bullet t-2}^{0} \zeta_{\bullet t-2}^{0}}
$$

and a set of four dummy variables that ordinally measured the individual's financial condition in $t-2$ from the main HRS survey. Descriptive statistics for selected variables used in our empirical analysis are shown in Table 5.

\section{Explaining Employer Match Rates}

Before discussing the instrumental variable estimates, we empirically examine two prominent explanations for why firms provide matching, in order to motivate the conditioning variables we use in $x_{1}$ and $x_{2}$ in (34). Ippolito (1997) argued that firms use matching to reward employees who have desirable, but unobservable, characteristics. These characteristics, in turn, are correlated with the employee's latent demand for deferred compensation, so that in equilibrium workers with these qualities sort to firms with matches. The primary example of such an unobservable quality is the discount

\footnotetext{
26 These calculators are discussed in detail in the data appendix. The effect of additional earnings on the employer match to voluntary contributions, $M_{y^{l}}$, was calculated assuming a $401(\mathrm{k})$ contribution of 50 dollars for all individuals (regardless of actual contribution level).
} 
rate. ${ }^{27}$ Endogenous sorting based on the discount rate has been a major criticism of “eligibility experiment" studies of the impact of $401(\mathrm{k}) \mathrm{s}$ on household saving. ${ }^{28}$

An alternative view is that matching may be adopted to raise the saving of rank and file employees so that highly compensated employees can take greater advantage of tax deferral. This view is widely espoused in the pension planning literature. In particular, the marginal benefit to the employee of tax deferral rises with the marginal tax rate, but deferred compensation may be curtailed by non-discrimination rules that limit the fraction of deferred compensation accruing to highly compensated employees (Garrett, 1995). In the situation in which non-discrimination constraints are (near) binding, the firm has a number of options that are not mutually exclusive. Naturally, it can adopt a matching scheme to raise participation and contributions. However, it also can adopt more flexible plan characteristics, such as hardship withdrawals, borrowing, and greater emphasis on self-directed investment, and may sponsor retirement planning seminars and financial education. It also can reduce the deferrals of highly-compensated employees by adopting contribution limits less than the federal allowable limit, and may offer an after-tax saving option (especially to highly-compensated employees). ${ }^{29}$

To test these competing hypotheses and motivate the conditioning variables in the contribution equation, Table 6 presents estimates of a Tobit model on the sample of 1,042 individuals in which the dependent variable is the first-dollar employer match rate. In

\footnotetext{
${ }^{27}$ Specifically, firms value those with low discount rates because they have a higher value of marginal product because they internalize the long-term implications of their current performance. Hence, those with a low discount rate are relatively more productive. However, because monitoring is costly, the firm cannot perfectly observe the worker's discount rate. In this framework, the firm can reward the unobservably higher marginal product workers with matching contributions, because workers with low discount rates place a higher value on deferred compensation than high discount rate workers.

${ }_{28}^{28}$ Poterba, Venti, and Wise $(1994,1995)$.

${ }^{29}$ The firm also can adopt automatic enrollment (Madrian and Shea, 2000). Although popular now, none of the HRS plans in 1992 had automatic enrollment.
} 
column 1, the explanatory variables are various measures of the individual's discount rate: dummy variables for whether currently smokes, ever smoked, planning horizon, and subjective probabilities of living beyond 75 and 85 , respectively. It also contains the risk measures described in Barksy, Juster, Kimball, and Shapiro (1998), demographic, and self-reported health variables. The estimates indicate that the discount rate variables (individually and jointly) do not predict the match rate. In column 2 , dummy variables for whether the plan allows borrowing, hardship withdrawals, self-directed investment, has an after-tax saving option, a limit less than the federal limit, or other traditional pension features were added. The estimation results show no correlation with measures of the discount rate, but other plan characteristics are highly significant. For example, plans that allow borrowing, self-directed investment, have other traditional features, have limits less than the federal limit, and after-tax saving options statistically significantly have higher first-dollar employer match rates. These results are consistent with the nondiscrimination view and inconsistent with the sorting view.

If the non-discrimination view is correct, then firms that are closer to the nondiscrimination constraints because of the distribution of pay in their industries, should have higher employer match rates. To measure this, we used federal non-discrimination rules, calculated the share of highly-compensated employees in the individual's industryunion-firm-size-Census-region cell from the 1989 March CPS, weighted by the individual combined federal-state marginal-tax-rate (which measures the tax benefit of deferred compensation), and added this variable to the model in column $3 .{ }^{30}$ In addition, we added dummies for firm-size category and union. We also added dummies for whether the employer offered a retirement seminar, and fringe benefit offerings at the

\footnotetext{
${ }^{30}$ The construction of this variable is described in detail in the data appendix.
} 
firm (long-term disability, group term life insurance, number of health insurance plans, number of retiree health insurance plans, weeks paid vacation, and days of sick pay), because firms that offer a generous employer match may offer a more generous fringe benefits package as well. The estimates in column 3 indicate that the greater the share of highly-compensated employees, the larger the match rate, consistent with the nondiscrimination view. Firms offering paid sick leave, long-term disability, and retiree health insurance have higher match rates. Column 4 replicates the specification in column 3, but with the dollar amount of the employer match as the dependent variable, and the results are similar. Overall, there is no evidence that workers with low discount rates are in plans with high match rates.

\section{Estimation Results}

To compare the non-linear budget set approach with that from the previous literature, we first estimated a series of ad hoc reduced-form specifications similar in spirit to those in the literature. ${ }^{31}$ These results are shown in Table 7. Column 1 shows a probit specification for the decision to contribute to the 401(k) plan in 1991. In columns $2-4$, the dependent variable is the dollar amount of contributions. Contributions are modeled as a function of earnings, demographics, a dummy for whether the firm matches contributions and the marginal match rate in column 2. Column 3 expands the specification to include quartic functions in age and earnings. Column 4 presents onelimit Tobit estimates. Like the studies in Table 1, all specifications in Table 5 indicate that the presence of a match raises contributions. However, conditional on offering a

\footnotetext{
${ }^{31}$ By "reduced-form," we do not mean the reduced-form from the structural IV in which the instruments appear as explanatory variables. Instead, we mean those relatively atheoretical specifications done by others in the literature listed in Table 1.
} 
match, the point estimates that increases in the match rate reduce contributions, but none of these effects are statistically significant.

Panel A of Table 8 presents the two-limit Tobit IV parameter estimates from (34). The results in Table 6 make clear the importance of controlling for other plan and employer characteristics when modeling 401(k) contributions. In particular, in column 1 of Table 8 , we include all of the explanatory variables for demographics, self-reported health status, risk characteristics, discount rates, fringe benefits, and other plan characteristics in column 2 of Table 6 in $x_{1}$ in (34). Thus, we assume that the variation in the instrument, $\Delta p^{z}$, across plans is exogenous conditional on these variables in $x_{1}$ and $x_{2}$. Panel $\mathrm{C}$ of the table gives the $p$-values for the test of the null hypothesis that each of the key measures (the match rate, income, net wage, and relative after-tax price of 401(k) to IRA saving) has no impact on contributions. Full income is the only variable for which the hypothesis cannot be rejected at conventional significance levels.

Elasticities of $401(\mathrm{k})$ contributions with respect to each of the key variables, evaluated at the sample means, are shown in Panel E of the table. In column 1, the uncompensated total match rate elasticity is 0.27 and statistically different from zero, which indicates that if the employer match were raised from fifty cents to one dollar, contributions would rise by twenty-seven percent. The income elasticity is negative, but small, and not statistically different from zero. The estimated net wage elasticity is 0.40 and statistically different than zero. The elasticity of the relative after-tax price of $401(\mathrm{k})$ versus IRA saving should be negative if 401(k)s and IRAs are substitutes. This is indeed the case, as the estimated elasticity is -0.61 . Fifth, the marginal utility of income must be non-negative. The estimated marginal utility of income is positive. 
We performed two robustness checks for these results. First, columns 2-4 add progressively more variables including dummy variables for whether the firm offered a retirement seminar and the extent to which the respondent discussed retirement with coworkers, whether the spouse's firm offered a retirement seminar and the extent to which the spouse discussed retirement with co-workers, firm size, Census division, union, and the tax-weighted share of highly compensated employees in the worker's state-industryemployer size cell. Column 3 adds interactions of the discount rate variables with demographics. Column 4 adds interactions of the plan characteristics, fringe benefit, and seminar variables and the demographics. Across all specifications in the table, the estimates are quite robust, suggesting uncompensated match rate elasticities of 0.27 .

Second, because the Tobit constrains the parameter estimates to be equal on the extensive and intensive margins, we estimated instrumental variable probit models on the same specifications. We then compared the probit participation elasticities, shown in Panel E of Table 8, to those from the Tobit model calculated using the McDonald-Moffitt (1980) decomposition, shown in Panel D, as a specification check, which almost always fails in empirical studies of saving and portfolio choice. Although we do not have confidence intervals for these elasticities, the two sets of elasticities are quite similar. In particular, the income and net wage elasticities are very similar. The match rate elasticity from the Tobit is somewhat smaller than that from the probit. The Tobit elasticities suggest that about sixty percent of the impact of a change in the match rate would be on the participation margin, with the remaining forty percent on the intensive margin.

Table 9 shows additional robustness results for the match rate elasticity. Because we have more than one individual in some plans, we estimated the same four 
specifications in Table 8 allowing for a random plan effect. The estimated match rate elasticities are shown in panel A of Table 9, and are quite similar to those in panel D of Table 8. In addition, we estimated models based on marginal utility of income quadratic and log-linear in the net wage and income shown in (35) and (36), respectively. These results are shown in panels $\mathrm{B}$ and $\mathrm{C}$ of Table 9, respectively. To make the results in these panels comparable to those in Table 8, the control variables in columns 1-4 are the same as those in columns 1-4 of Table 8 . The implied total elasticities were qualitatively similar, but somewhat smaller, ranging from 0.15-0.20.

\section{Conclusion}

Previous studies have failed to recognize that employer matching based either on a multiple match-rate schedule or caps on the generosity of the match induce kinks in the intertemporal budget constraint. As has been long recognized in the study of taxation on labor supply, reduced-form estimates of behavioral elasticities are biased and inconsistent unless these kinks are accounted for explicitly. Indeed, we replicated typical findings from the reduced-form literature in our dataset. Specifically, we estimated that the existence of a matching program raises 401(k) saving, but conditional on offering a match, higher match rates lower contributions. In contrast, our richest structural specifications imply an uncompensated elasticity of $401(\mathrm{k})$ saving with respect to the match rate of $0.15-0.27$ overall, and $0.09-0.16$ and $0.06-0.11$ on the extensive and intensive margins, respectively.

We draw two main conclusions from the structural estimates. First, these elasticities suggest that $401(\mathrm{k})$ saving is responsive to changes in the after-tax rate of return. Second, our analysis suggests that failure to account for kinks in the intertemporal 
budget set has biased substantially previous estimates of the effect of matching on $401(\mathrm{k})$ contributions, so badly, in fact, that the reduced-form estimates can be of the wrong sign.

A number of commonly advocated reforms to the Social Security system call for the introduction of voluntary private accounts, whereby individuals could choose to contribute additional funds toward Social Security. Under some reform proposals, the federal government would match those contributions as an incentive. In determining the optimal match rate (given the government's other revenue needs), it would be instrumental for policy makers to know how individual contributions would respond to the government match. Clearly, much could be learned in this context from the experience of employer matching for 401(k)s. Finally, a number of prominent companies have reduced or eliminated matching contributions recently due to declining profits. Although it remains to be seen if this is a long-term trend, understanding the impact of matching is critical to understanding the impact of these changes on retirement income security for a workforce increasingly dependent on 401(k) plans for retirement. 


\section{References}

Agnew, Julie, Pierluigi Balduzzi, and Annika Sunden, "Portfolio Choice and Trading in a Large 401(k) Plan," American Economic Review 93:1 (2003): 193-215.

Andrews, Emily S., "The Growth and Distribution of 401(k) Plans," in Trends in Pensions 1992, John A. Turner and Daniel J. Beller, eds. (Washington, DC: U.S. Department of Labor) 1992, pp. 149-176.

Barksy, Robert B., F. Thomas Juster, Miles S. Kimball, and Matthew D. Shapiro, "Preference Parameters and Behavioral Heterogeneity: An Experimental Approach in the Health and Retirement Study," Quarterly Journal of Economics 112:2 (1998): 537-580.

Bassett, William F., Michael J. Fleming, and Anthony P. Rodrigues, "How Workers Use 401(k) Plans: The Participation, Contribution, and Withdrawal Decisions," National Tax Journal 51:2 (1998): 263-289.

Benartzi, Shlomo, and Richard H. Thaler, "Naïve Diversification Strategies in Defined Contribution Saving Plans," American Economic Review 91:1 (2001): 79-98.

Blundell, Richard, and Thomas MaCurdy. (1999) "Labor Supply: A Review of Alternative Approaches." In Handbook of Labor Economics, Volume 3A, edited by Orley Ashenfelter and David Card, Amsterdam: North Holland.

Boskin, Michael, "Taxation, Savings, and the Rate of Interest," Journal of Political Economy 86 (1978), S3-S27.

Carroll, Christopher D. (1992). "The Buffer-Stock Theory of Saving: Some Macroeconomic Evidence," Brookings Papers on Economic Activity, 2, 61-156.

Choi, James J., David Laibson, Brigitte Madrian, and Andrew Metrick, "For Better or For Worse: Default Effects and 401(k) Savings Behavior," NBER Working Paper No. 8651, 2001.

Choi, James J., David Laibson, Brigitte Madrian, and Andrew Metrick, "Defined Contribution Pensions: Plan Rules, Participant Decisions, and the Path of Least Resistance," in James M. Poterba, ed., Tax Policy and the Economy, Vol. 16 (Cambridge, MA: MIT Press), 2002.

Clark, Robert L. and Sylvester J. Schieber, "Factors Affecting Participation Rates and Contribution Levels in 401(k) Plans," in Living with Defined Contribution Pensions: Remaking Responsibility for Retirement, Olivia S. Mitchell and Sylvester J. Schieber, eds. (Philadelphia: University of Pennsylvania Press), 1998, pp. 69-97.

Coile, Courtney, and Jonathan Gruber, "Social Security and Retirement," NBER Working Paper No. 7830, 2000. 
Cunningham, Christopher R., and Gary V. Engelhardt, 'Federal Tax Policy, Employer Matching, and 401(k) Saving: Evidence from HRS W-2 Records," National Tax Journal, 2002.

Employee Benefit Research Institute, Salary Reduction Plans and Individual Saving for Retirement, Issue Brief No. 155 (Washington, DC: Employee Benefit Research Institute), 1994.

Engelhardt, Gary V., "Have 401(k)s Raised Household Saving? Evidence from the Health and Retirement Study," Mimeo., Syracuse University, 2001.

Engelhardt, Gary V., "Pre-Retirement Lump-Sum Pension Distributions and Retirement Income Security: Evidence from the Health and Retirement Study," National Tax Journal 55:4 (December) 2002: 665-686.

Engen, Eric M., William G. Gale, and John Karl Scholz, "Do Saving Incentives Work?," Brookings Papers on Economic Activity 2 (1994): 85-180.

Even, William E., and David A. Macpherson, "Factors Influencing Employee Participation in 401(k) Plans," Mimeo, Miami University (Ohio), 1996.

Feenberg, Daniel, and Elisabeth Coutts, "An Introduction to the TAXSIM Model," Journal of Policy Analysis and Management 12 (1) (Winter) (1993): 189-194.

Feldstein, Martin, "Social Security, Induced Retirement, and Aggregate Capital Accumulation," Journal of Political Economy 82 (1974): 905-926.

Friedberg, Leora, and Anthony Webb, "Retirement and the Evolution of the Pension Structure,” NBER Working Paper No. 9999, 2003.

Garrett, Daniel, "The Effects of Nondiscrimination Rules on 401(k) Contributions," Mimeo., Stanford University, 1995.

General Accounting Office, "401(k) Pension Plans: Loan Provisions Enhance Participation But May Affect Income Security for Some," Report GAO/HEHS-98-5, 1997.

Gustman, Alan L., and Thomas L. Steinmeier, "An Analysis of Pension Benefit Formulas, Pension Wealth, and Incentives from Pensions," Research in Labor Economics 10 (1989): 53-106.

Gustman, Alan L., and Thomas L. Steinmeier, "What People Don't Know About Pensions and Social Security: An Analysis Using Linked Data from the Health and Retirement Study," NBER Working Paper No. 7368, 1999. 
Gustman, Alan L., Olivia S. Mitchell, Andrew A. Samwick, and Thomas L. Steinmeier, "Pension and Social Security Wealth in the Health and Retirement Study," in Wealth, Work, and Health: Innovations in Measurement in the Social Sciences, James Smith and Robert Willis, eds. (Ann Arbor: University of Michigan Press) 1999, pp. 150-208.

Hausman, Jerry A., "The Econometrics of Nonlinear Budget Sets," Econometrica (November) 53 (1985), 1255-1282.

Ippolito, Richard A. Pension Plans and Employee Performance, Chicago: University of Chicago Press, 1997.

Johnson, Richard W., Usha Sambamoorthi, and Stephen Crystal. "Pension Wealth at Midlife: Comparing Self-Reports with Provider Data." Review of Income and Wealth 46(1) (2000), 59-83

Joines, Douglas H., and James G. Manegold. "IRAs and Saving: Evidence from a Panel of Taxpayers." Mimeograph, Table 8. University of Southern California, September 1991.

Joulfaian, David, and David Richardson, "Who Takes Advantage of Tax-Deferred Savings Programs? Evidence from Federal Income Tax Data," National Tax Journal 54 (2001): 669-688.

Kusko, Andrea, James M. Poterba, and David Wilcox, "Employee Decisions With Respect to 401(k) Plans," in Living with Defined Contribution Pensions: Remaking Responsibility for Retirement, Olivia Mitchell and Sylvester Schieber, eds. (Philadelphia: University of Pennsylvania Press) 1998, pp. 98-112.

MaCurdy, Thomas E., David Green, and Harry Paarsch, "Assessing Empirical Approaches for Analyzing Taxes and Labor Supply," Journal of Human Resources 25 (Summer 1990): 415-90.

Madrian, Brigitte C., and Dennis F. Shea, "The Power of Suggestion: Inertia in 401(k) Participation and Savings Behavior," Quarterly Journal of Economics 116 (2001): 114987.

McDonald, John F., and Robert A. Moffitt, "The Uses of Tobit Analysis," Review of Economics and Statistics 62 (1980): 318-321.

Mitchell, Olivia S., "Worker Knowledge of Pension Provisions," Journal of Labor Economics 6 (1988): 21-39.

Mitchell, Olivia, Jan Olson, and Thomas Steinmeier, "Construction of the Earnings and Benefits File (EBF) for Use with the Health and Retirement Survey," HRS/AHEAD Documentation Report No. DR-001, Institute for Social Research, University of Michigan, 1996. 
Moffitt, Robert A., "The Econometrics of Kinked Budget Constraints," Journal of Economic Perspectives 4 (1990): 119-139.

Munnell, Alicia H., Annika Sunden, and Catherine Taylor, "What Determines 401(k) Participation and Contributions?" Mimeo., Boston College, 2001.

Newey, Whitney K., "Linear Instrumental Variable Estimation of Limited Dependent Variable Models with Endogenous Explanatory Variables," Journal of Econometrics 32 (1986): 127-141.

Papke, Leslie E., "Participation in and Contributions to 401(k) Pension Plans: Evidence from Plan Data," Journal of Human Resources 30:2 (1995): 311-325.

Papke, Leslie E., Poterba, James M, "Survey Evidence on Employer Match Rates and Employee Saving Behavior in 401(k) Plans", Economics Letters 49, 313-317, 1995.

Poterba, James M, "Employer Stock and 401(k) Plans," American Economic Review, 93:2 (2003): 398-404.

Poterba, James M., Steven F. Venti, and David A. Wise, "401(k) Plans and Tax-Deferred Saving," in Studies in the Economics of Aging, David A. Wise, ed., (Chicago: University of Chicago Press) 1994, pp. 105-42.

Poterba, James M., Steven F. Venti, and David A. Wise, "Do 401(k) Contributions Crowd Out Other Personal Saving?” Journal of Public Economics 58 (1995): 1-32.

Rohwedder, Susann, "Empirical Validation of HRS Pension Wealth Measures," Mimeo., Rand Corporation, 2003a.

Rohwedder, Susann, "Measuring Pension Wealth in the HRS: Employer and SelfReports," Mimeo., Rand Corporation, 2003 b.

Starr-McCluer, Martha, and Annika Sunden, "Workers' Knowledge of Their Pension Coverage: A Reevaluation” Mimeo., Federal Reserve Board of Governors, 1999.

Summers, Lawrence H., "Capital Taxation and Accumulation in a Life Cycle Model," American Economic Review 71 (1981): 533-544.

Ziliak, James P., and Thomas J. Kniesner, 'Estimating Life Cycle Labor Supply Tax Effects,” Journal of Political Economy 107:2 (1999): 326-359. 


\section{Appendix}

This appendix describes the construction of and gives background on the dataset. The material on the construction of 401(k) contributions draws heavily on the discussion in Cunningham and Engelhardt (2002).

Match Rates --- The restricted-access firm pension plans are distributed as the HRS Wave 1 Pension Plan Detail Data Set. This dataset contains plan type, eligibility rules, benefit formulae, employer contribution and matching formulae, early and normal retirement dates, and other information described in the SPD, but not any information for individual employees. We use these detailed plan descriptions to construct the complete schedule of employer matching contributions for each individual in our sample. There are primarily 4 types of matching: fixed rate, discretionary matches, matches based on profit sharing, and variable-rate matches. Fixed rate matches are either calculated as a fixed percentage of respondent's contribution or a fixed dollar amount. Discretionary matches and profit sharing matches were dropped from our sample because it is not possible to construct the matching schedule.

401(k) Contributions --- We follow Cunningham and Engelhardt (2002) and measure 401(k) contributions in 1991 from the W-2 data as follows. First, 401(k)s are excluded from federal income taxation (in the year contributed), but are subject to the Social Security (FICA) payroll tax. Let $y$ be the total calendar year wages and salary and $c$ the calendar year wages and salary deferred through a 401(k) contribution. Then $w=y-c$ is the amount of annual earnings net of $401(\mathrm{k})$ contribution, i.e., non-tax-deferred earnings. $w$ is the amount reported in the Wages, Tips, and Other Compensation box on IRS Form W-2 and is recorded in the matched W-2 earnings records for HRS individuals. 401(k) contributions are included in the Medicare payroll tax base. Hence, $y$ is the amount reported in the Social Security Wages box on the W-2 and is recorded in the matched W-2 earnings records for HRS individuals. The difference between W-2 Wages, Tips, and Other Compensation and Medicare Wages will measure 401(k) contributions, i.e., $y-w=y-(y-c)=c$. Because this method is feasible only for individuals with annual earnings below the Medicate taxable maximum earnings level of $\$ 125,000$ in 1991, we excluded all individuals with earnings exceeding the Medicare cap in 1991. Contributions to flexible benefit plans through employee salary reduction (e.g., premium conversion plans, cafeteria plans, and flexible spending accounts, including medical and dependent care reimbursement accounts) are exempt from both Social Security and Federal income tax, and do not affect this method of calculating 401(k) contributions.

Virtual Income - To calculate full income, detailed information on the gross wage, $w$, non-capital unearned income, $B$, capital income, $r W^{A}$, and two periods of financial

wealth to calculate $\Delta W^{A}$ are needed. In addition, information detailed enough to calculate the marginal tax rates and IRA deductibility phase out, and total taxes paid, $T$, are needed. Finally, detailed pension plan data on match rates and caps are needed to construct the budget set, and, along, with the tax data, virtualize the full income measure. 
We use the HRS, probably the only data set currently available appropriate to perform this type of study. As described above, the HRS surveyed 51-61 year olds and their spouses (regardless of age) in 1992. It asked detailed questions about household income, IRA contributions, tax information, wealth, demographics, spousal characteristics, and employment. We estimate our specifications for 401(k) contributions made during calendar year 1991. Specifically, the respondent-reported income, IRA contributions, and tax questions were asked in 1992 about behavior in calendar year 1991. The income questions allowed us to construct non-capital unearned income, $B$. The survey asked about financial wealth in 1992 at the time of the survey. To formulate $\Delta W^{A}$ in full income, we also needed financial wealth in 1991. This was not asked about directly in the 1992 survey, but capital income in 1991, $r W^{A}$, was asked. Thus, we derived financial wealth in 1991 by capitalizing the 1991 capital income (Joines and Manegold (1991)). We used the household income, tax, and demographic data and NBER's TAXSIM calculator to construct marginal tax rates, IRA phase out, and taxes paid for each household.

Overall, there are 1717 matched SPDs for all plans combined, including defined benefit plans. Of these, 658 are defined contribution plans that allow for voluntary pretax employee contributions. Our sample consists of 727 individuals in 343 plans. We used just 363 of the 658 plans for two reasons. First, only about 75 percent of HRS respondents gave permission to match their W-2 records from which we measure contributions and pay, so that we lose about 25 percent of the 658 plans due to missing W-2s. Second, the HRS only collected respondent-reported information on the current job (or most recent job if retired) as of the interview date in 1992 and prior jobs that lasted five years or longer. For individuals who changed jobs between the end of 1991 and the survey date, the SPDs that were collected for the current job in 1992 did not apply to the 1991 job, so these individuals were excluded even though they had valid W2 data. For individuals whose jobs in 1991 did not last five years or longer and who had a new job in 1992, the HRS did not attempt to collect an SPD, so these individuals were excluded as well. Table 4 gives descriptive statistics for our sample. ${ }^{32}$

Construction of Smooth and Differentiable Budget Constraint - The data on kinks and match rates for different segments of the budget sets was prepared using a SAS program. This program required the respondents' wages as input. The HRS pension plan data was used to find the contribution levels at which the employer match rates changed. There are primarily 3 types of matching: fixed rate, discretionary matches and variable rate matches. Fixed rate matches are either calculated as a fixed percentage of respondent's contribution or a fixed dollar amount. The HRS pension plan data is dominated by the former method. Discretionary matches were ignored in estimation. Like the fixed rate matches, variable rate matches are specified as a percentage of respondents' contribution or a dollar amount. However conditional on how they are calculated, variable rate matches vary in match rates over other dimensions like voluntary contribution as a

\footnotetext{
32 The W-2 data are distributed as the HRS Wages and Self-Employment Income in Covered and NonCovered Jobs dataset [Mitchell, Olson, and Steinmeier (1996)]. This database also includes income from self-employment reported on Form 1040, Schedule C.
} 
percentage of pay, actual years of service, age or a combination of age and actual years of service. Variation of these match rates over the respondents' contribution schedule creates kinks in the budget set. If these variable rate matches vary with age and actual years of service, no intratemporal kinks are created as they do not vary with levels of voluntary contribution. A typical variable rate matching has declining match rates as a function of contribution as a percent of pay.

Most plans also have an overall match cap beyond which matches to respondent's contributions are no longer made. The kinks in the budget set of respondents with fixed rate matches are created by this restriction. A typical match cap is 3-6\% of respondent's pay, creating a kink at the evel of voluntary contributions at this level of pay. Thus, fixed rate matches can create at most one interior kink. On the other hand, variable rate matches can create multiple kinks in the respondent's budget set. These variable rate matches are also subject to the global restriction on matching imposed by a match cap when contributions reach a certain percentage of salary.

HRS pension plan data has detailed information on both fixed as well as variable rate matches. Once the kinks are defined it is easy to find the slope of the budget set for every segment. These match rates are an important input in finding the slopes of a respondent's various segments of the budget set. Changes in the match rates along the respondent's intertemporal budget set create much sharper kinks than changes in the tax rates.

Taxes are another important ingredient of the slope of the budget set. Due to the restricted nature of the data, we constructed a grid of adjusted gross incomes (AGI) from $\$ 50$ to $\$ 350,000$. We then used NBER's TAXSIM to generate marginal tax rates at every level of AGI in $\$ 50$ interval conditional on tax status defined by every combination of tax marital status, number of dependents, and age exemption. The marginal tax rate $\tau$ for this synthetic taxpayer was obtained from this grid.

Employer matching and federal tax deductibility of 401(k) induce implicit taxation of 401(k) contribution over the opportunity set. These implicit taxes also depend upon to which pension plan the individual belongs. To construct the individual's budget set, we created a grid of income levels corresponding to individual's contribution from $\$ 0$ to $\$ 9500$, which is the maximum possible contribution. Thus we created 191 income levels for every individual which mapped into every possible contribution level in $\$ 50$ interval.

Noting that the budget set can have multiple kinks depending on a combination of match rates and marginal tax rates, and can have multiple points of nondifferentiability, we constructed a differentiable budget constraint using a method suggested by MaCurdy, Green, and Paarsch (1990) and implemented by Ziliak and Kniesner (1999), to smooth the budget set around the kink points. We fitted a cubic polynomial of implicit tax rates on income where implicit taxes were calculated as $t=[1-(1+m) /(1-t)]$.

Because the marginal implicit tax rate is a smooth and continuously differentiable function of taxable income, we can integrate the function back to obtain total implied tax 
payments. Using the coefficients from the polynomial regression, we were able to get the implicit tax rates at income levels corresponding to each contribution level in $\$ 50$ intervals. As an alternative we also used kernel regression of implicit tax rate on federal marginal tax rates to smooth the budget set. The bandwidth for the kernel regression was chosen using Silverman's rule of thumb, by first finding $m=\min \left(\sqrt{\operatorname{variance} x_{x}}, \frac{i q r_{x}}{1.349}\right)$ where $i q r_{x}$ is the interquartile range. Then the bandwidth can be computed as ${ }_{h=\frac{0.9 m}{n^{\frac{1}{5}}}}$. The choice of kernel in the Kernel Regression was the Gaussian kernel which is given by $K(z)=\frac{1}{\sqrt{2 \pi}} e^{-z^{2} / 2}$. Kernel estimates seemed to fit the data better than a cubic polynomial. A smooth marginal implicit tax rate function can be integrated to obtain the implicit tax. We numerically integrated the differentiable marginal implicit tax rate function over the range income corresponding to zero $401(\mathrm{k})$ contribution to maximum $401(\mathrm{k})$ contribution to obtain the implicit tax for every level of 401(k) contribution.

Mathematically, the implicit tax $t$ is a function of individual's income at different levels of 401(k) contributions

$$
t=f\left(I\left(Q^{401(k)}\right)\right)
$$

The total implicit tax is

$$
T=\int f\left(I\left(Q^{401(k)}\right)\right) d I\left(Q^{401(k)}\right)
$$

We numerically integrated (3) to obtain $T$. Then the virtual income was calculated as

$$
Y_{t}^{v}=Y_{t}+\left(t^{*} Q^{401(k)}-T^{Q_{40(k)}}\right) \text {. }
$$

$Y_{t}^{v}$ contains a component to compensate the individual as he does not face the marginal implicit tax rate for his entire 401(k) contribution. 
Table 1: Summary of Results from Selected Previous Studies

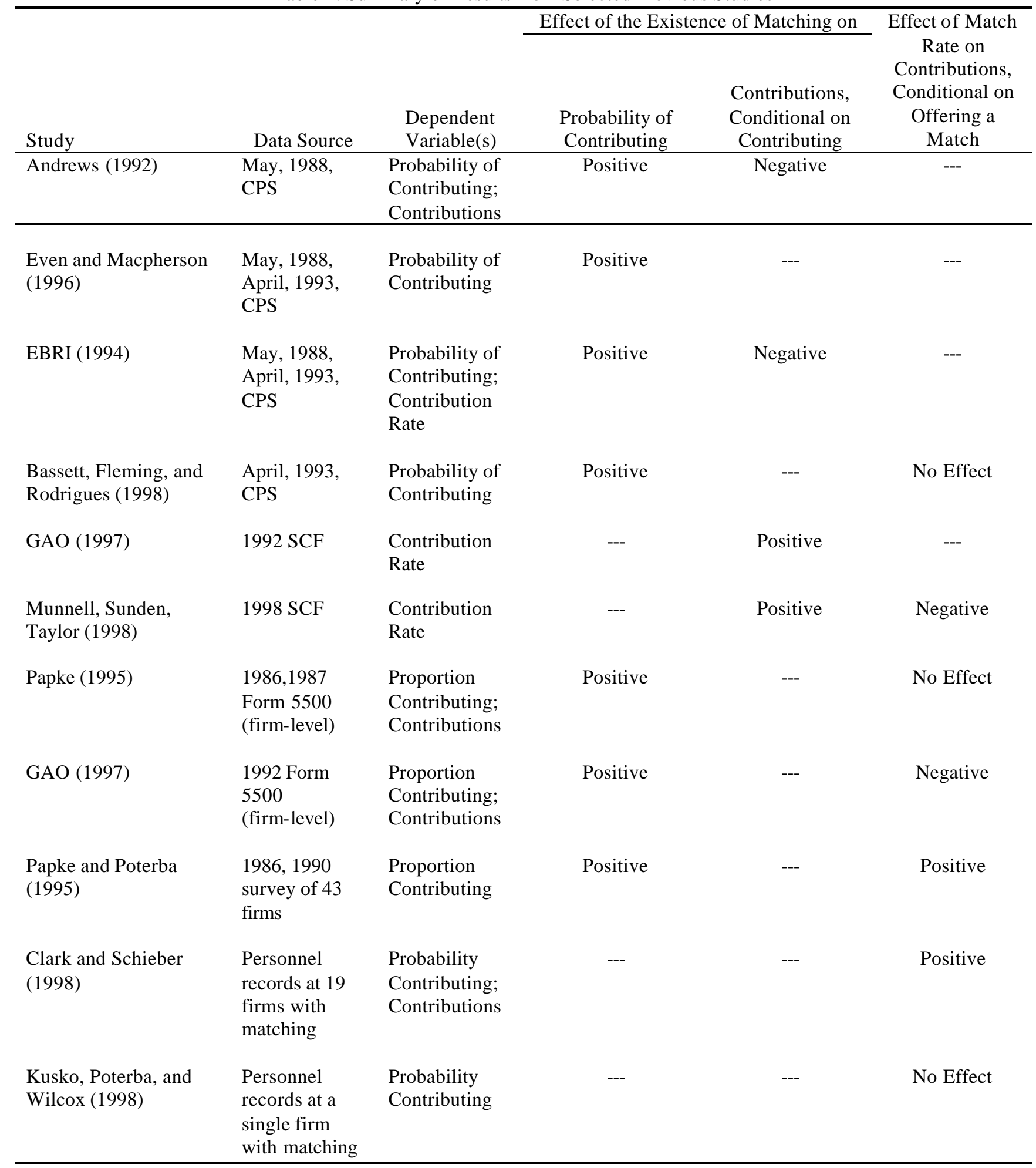

Note: All studies above estimated reduced-form specifications. The contribution rate in these studies is measured as annual contributions as a percent of income. 
Table 2. Distribution of 401(k) Plans in the HRS, by Type of Matching

\begin{tabular}{|c|c|c|}
\hline & $\begin{array}{c}\text { (1) } \\
\text { All 401(k) } \\
\text { Plans in the } \\
\text { HRS }\end{array}$ & $\begin{array}{c}(2) \\
\text { All 401(k) } \\
\text { Plans in the } \\
\text { Analysis Sample }\end{array}$ \\
\hline Category & Percent & Percent \\
\hline $\begin{array}{l}\text { Percent Plans Offering Employer } \\
\text { Match }\end{array}$ & 52 & 54 \\
\hline \multicolumn{3}{|l|}{$\begin{array}{l}\text { Of Plans with Match, Percent } \\
\text { with }\end{array}$} \\
\hline Discretionary Match & 1 & 0 \\
\hline Match Through Profit-Sharing & 9 & 0 \\
\hline Fixed Rate Match & 73 & 80 \\
\hline Variable Rate Match & 17 & 20 \\
\hline
\end{tabular}


Table 3. Cap on Matching Contributions, as a Percentage of Pay, for All Plans in the Analysis Sample

\begin{tabular}{ccccc}
\hline $\begin{array}{c}\text { Cap on Employer Matching } \\
\text { Contributions }\end{array}$ & $\begin{array}{c}(1) \\
\text { Number of } \\
\text { as a Percentage of Pay }\end{array}$ & $\begin{array}{c}\text { Percent of } \\
\text { Plans }\end{array}$ & $\begin{array}{c}\text { Number of } \\
\text { Individuals }\end{array}$ & $\begin{array}{c}\text { Percent of } \\
\text { Individuals }\end{array}$ \\
\hline Less than $2 \%$ & 7 & 3.3 & 10 & 2.7 \\
2 & 11 & 5.3 & 12 & 3.2 \\
2.5 & 1 & 0.5 & 1 & 0.3 \\
3 & 19 & 9.1 & 24 & 6.5 \\
3.75 & 1 & 0.5 & 4 & 1.0 \\
4 & 23 & 11.0 & 40 & 10.8 \\
5 & 17 & 8.1 & 53 & 14.2 \\
5.5 & 1 & 0.5 & 1 & 0.3 \\
5.7 & 1 & 0.5 & 1 & 0.3 \\
6 & 56 & 26.8 & 109 & 29.3 \\
Greater than 6\% & 32 & 15.3 & 57 & 15.3 \\
No Cap & 41 & 19.6 & 60 & 16.1 \\
Total & 209 & 100.0 & 372 & 100.0 \\
\hline
\end{tabular}

Note: Authors' calculations from the HRS restricted-access pension plan data for the 209 plans associated with the 372 of the $1042 \mathrm{HRS}$ individuals in the analysis sample in plans with matching provisions. 
Table 4. Distribution of First-Dollar Match Rates as a Percentage of Contributions

(1)

(2)

(3)

(4)

(5)

\begin{tabular}{|c|c|c|c|c|}
\hline First-Dollar Match Rate (\%) & $\begin{array}{c}\text { Number of } \\
\text { Plans }\end{array}$ & $\begin{array}{l}\text { Percent of } \\
\text { Plans }\end{array}$ & $\begin{array}{l}\text { Number of } \\
\text { Individuals }\end{array}$ & $\begin{array}{l}\text { Percent of } \\
\text { Individuals }\end{array}$ \\
\hline 0 to 24 & 9 & 4.3 & 11 & 3.0 \\
\hline 25 & 23 & 15.3 & 43 & 11.6 \\
\hline 26 to 49 & 5 & 2.4 & 9 & 2.4 \\
\hline 50 & 90 & 43.1 & 143 & 38.4 \\
\hline 51 to 99 & 22 & 8.1 & 34 & 12.4 \\
\hline 100 & 57 & 27.2 & 116 & 31.2 \\
\hline 200 & 3 & 1.4 & 4 & 1.1 \\
\hline Total & 209 & 100.0 & 372 & 100.0 \\
\hline
\end{tabular}

Note: Authors' calculations from the HRS restricted-access pension plan data for the 209 plans associated with the 372 of the 1042 HRS individuals in the analysis sample in plans with matching provisions. 
Table 5. Sample Means of Selected Variables in the Empirical Analysis Sample, Standard Deviations in Parentheses, Medians in Square Brackets

(1)

(2)

(3)

(4)

(5)

\begin{tabular}{|c|c|c|c|c|c|}
\hline Variable & Full Sample & $\begin{array}{c}\text { Subsample } \\
\text { without } \\
\text { Matches }\end{array}$ & $\begin{array}{c}\text { Subsample } \\
\text { with Matches }\end{array}$ & $\begin{array}{c}\text { Subsample with } \\
\text { Positive } \\
\text { Contributions }\end{array}$ & $\begin{array}{c}\text { Subsample } \\
\text { with Zero } \\
\text { Contributions }\end{array}$ \\
\hline $\begin{array}{l}\text { 401(k) Contributions (in } \\
1991 \text { dollars) }\end{array}$ & $\begin{array}{c}1377 \\
(1920) \\
{[500]}\end{array}$ & $\begin{array}{c}1232 \\
(1895) \\
{[100]}\end{array}$ & $\begin{array}{c}1640 \\
(1938) \\
{[900]}\end{array}$ & $\begin{array}{c}2446 \\
(1982) \\
{[1892]}\end{array}$ & $\begin{array}{c}0 \\
(0) \\
{[0]}\end{array}$ \\
\hline Match Rate (in percent) & $\begin{array}{c}23 \\
(37) \\
{[0]}\end{array}$ & $\begin{array}{l}0 \\
(0) \\
{[0]}\end{array}$ & $\begin{array}{l}65 \\
(32) \\
{[50]}\end{array}$ & $\begin{array}{c}28 \\
(38) \\
{[0]}\end{array}$ & $\begin{array}{c}17 \\
(33) \\
{[0]}\end{array}$ \\
\hline $\begin{array}{l}\text { After-Tax Wage } \\
\text { (in } 1991 \text { dollars per hour) }\end{array}$ & $\begin{array}{l}10.04 \\
(5.55) \\
{[8.92]}\end{array}$ & $\begin{array}{l}10.09 \\
(5.56) \\
{[9.12]}\end{array}$ & $\begin{array}{l}9.96 \\
(5.54) \\
{[8.51]}\end{array}$ & $\begin{array}{l}10.91 \\
(5.96) \\
{[9.66]}\end{array}$ & $\begin{array}{l}8.91 \\
(4.75) \\
{[8.23]}\end{array}$ \\
\hline Age (years) & $\begin{array}{c}54.9 \\
(5.2) \\
{[55.0]}\end{array}$ & $\begin{array}{c}54.9 \\
(5.1) \\
{[55.0]}\end{array}$ & $\begin{array}{c}54.8 \\
(5.4) \\
{[55.0]}\end{array}$ & $\begin{array}{c}54.7 \\
(5.0) \\
{[55.0]}\end{array}$ & $\begin{array}{l}55.1 \\
(5.5) \\
{[55.0]}\end{array}$ \\
\hline Education (years) & $\begin{array}{c}13.3 \\
(2.7) \\
{[13.0]}\end{array}$ & $\begin{array}{c}13.5 \\
(2.7) \\
{[13.0]}\end{array}$ & $\begin{array}{l}13.0 \\
(2.6) \\
{[12.0]}\end{array}$ & $\begin{array}{c}13.8 \\
(2.5) \\
{[14.0]}\end{array}$ & $\begin{array}{l}12.7 \\
(2.7) \\
{[12.0]}\end{array}$ \\
\hline Percent Female & 47 & 47 & 47 & 48 & 45 \\
\hline Percent White & 82 & 81 & 85 & 86 & 78 \\
\hline Number of Dependents & $\begin{array}{c}0.70 \\
(0.93) \\
{[0.0]}\end{array}$ & $\begin{array}{c}0.68 \\
(0.93) \\
{[0.0]}\end{array}$ & $\begin{array}{c}0.75 \\
(0.94) \\
{[0.0]}\end{array}$ & $\begin{array}{c}0.71 \\
(0.95) \\
{[0.0]}\end{array}$ & $\begin{array}{c}0.70 \\
(0.91) \\
{[0.0]}\end{array}$ \\
\hline Percent Married & 80 & 79 & 82 & 81 & 79 \\
\hline $\begin{array}{l}\text { Spouse's Education } \\
\text { (Years) }\end{array}$ & $\begin{array}{c}10.6 \\
(5.5) \\
{[12.0]}\end{array}$ & $\begin{array}{c}10.6 \\
(5.7) \\
{[12.0]}\end{array}$ & $\begin{array}{l}10.6 \\
(5.2) \\
{[12.0]}\end{array}$ & $\begin{array}{c}11.0 \\
(5.5) \\
{[12.0]}\end{array}$ & $\begin{array}{l}10.1 \\
(5.5) \\
{[12.0]}\end{array}$ \\
\hline $\begin{array}{l}\text { Percent with Plans that } \\
\text { Allow Borrowing }\end{array}$ & 36 & 19 & 68 & 42 & 29 \\
\hline $\begin{array}{l}\text { Percent with Plans that } \\
\text { Allow Hardship } \\
\text { Withdrawals }\end{array}$ & 4 & 4 & 5 & 6 & 2 \\
\hline
\end{tabular}




\begin{tabular}{|c|c|c|c|c|c|}
\hline Variable & Full Sample & $\begin{array}{l}\text { Subsample } \\
\text { without } \\
\text { Matches }\end{array}$ & $\begin{array}{c}\text { Subsample } \\
\text { with Matches }\end{array}$ & $\begin{array}{c}\text { Subsample } \\
\text { with Positive } \\
\text { Contributions }\end{array}$ & $\begin{array}{c}\text { Subsample } \\
\text { with Zero } \\
\text { Contributions }\end{array}$ \\
\hline $\begin{array}{l}\text { Percent with Plans that } \\
\text { Allow Self-Directed } \\
\text { Investment }\end{array}$ & 63 & 46 & 92 & 66 & 58 \\
\hline $\begin{array}{l}\text { Percent with Other } \\
\text { Pensions at the Firm }\end{array}$ & 47 & 53 & 34 & 45 & 48 \\
\hline $\begin{array}{l}\text { Percent with Plan Limit } \\
\text { less than Federal Limit }\end{array}$ & 80 & 73 & 92 & 76 & 85 \\
\hline $\begin{array}{l}\text { Percent with Plan that } \\
\text { Allows After-Tax Saving }\end{array}$ & 23 & 9 & 47 & 26 & 18 \\
\hline $\begin{array}{l}\text { Percent that had } \\
\text { Employer-Sponsored } \\
\text { Retirement Seminar }\end{array}$ & 23 & 23 & 23 & 25 & 20 \\
\hline $\begin{array}{l}\text { Percent with a Spouse } \\
\text { who has a Pension }\end{array}$ & 39 & 39 & 38 & 42 & 35 \\
\hline Percent in a Union & 34 & 39 & 27 & 28 & 43 \\
\hline Number of Observations & 1042 & 672 & 370 & 588 & 454 \\
\hline
\end{tabular}


Table 6. Tobit Estimates of the Relationship between the First-Dollar Match Rate, Other Plan Characteristics and Measures of the Discount Rate, t-Statistics in Parentheses

\begin{tabular}{|c|c|c|c|c|}
\hline \multirow[b]{3}{*}{ Explanatory Variable } & (1) & (2) & (3) & (4) \\
\hline & \multicolumn{4}{|c|}{ Dependent Variable } \\
\hline & $\begin{array}{l}\text { First-Dollar } \\
\text { Match Rate }\end{array}$ & $\begin{array}{l}\text { First-Dollar } \\
\text { Match Rate }\end{array}$ & $\begin{array}{l}\text { First-Dollar } \\
\text { Match Rate }\end{array}$ & $\begin{array}{c}\text { Potential } \\
\text { Employer Match } \\
\text { (in dollars) } \\
\end{array}$ \\
\hline Dummy if Planning & 0.083 & 0.082 & 0.061 & 0.006 \\
\hline Horizon is Next Year & $(0.63)$ & $(0.78)$ & $(0.59)$ & $(0.61)$ \\
\hline Dummy if Planning & 0.0004 & 0.070 & 0.027 & -0.005 \\
\hline Horizon is Next Few & $(0.001)$ & $(0.91)$ & $(0.34)$ & $(0.64)$ \\
\hline \multicolumn{5}{|l|}{ Years } \\
\hline Dummy if Planning & -0.004 & 0.091 & 0.072 & 0.001 \\
\hline Horizon is Next $5-10$ & $(0.04)$ & $(1.16)$ & $(0.92)$ & $(0.14)$ \\
\hline \multicolumn{5}{|l|}{ Years } \\
\hline Dummy if Planning & 0.157 & 0.088 & 0.053 & 0.003 \\
\hline Horizon is Longer than & $(1.25)$ & $(0.88)$ & $(0.53)$ & $(0.33)$ \\
\hline \multicolumn{5}{|l|}{10 Years } \\
\hline Subjective Probability & -0.006 & -0.006 & -0.004 & 0.000 \\
\hline of Living to 75 or & $(0.34)$ & $(0.44)$ & $(0.29)$ & $(0.14)$ \\
\hline \multicolumn{5}{|l|}{ More } \\
\hline Subjective Probability & 0.007 & -0.003 & -0.003 & -0.001 \\
\hline of Living to 85 or & $(0.42)$ & $(0.21)$ & $(0.23)$ & $(0.49)$ \\
\hline \multicolumn{5}{|l|}{ More } \\
\hline Dummy if Currently & 0.059 & 0.007 & 0.001 & -0.001 \\
\hline Smoke & $(0.69)$ & $(0.10)$ & $(0.02)$ & $(0.12)$ \\
\hline Dummy if Ever & 0.045 & 0.006 & 0.014 & 0.002 \\
\hline Smoked & $(0.61)$ & $(0.09)$ & $(0.24)$ & $(0.29)$ \\
\hline \multirow{2}{*}{\multicolumn{2}{|c|}{$\begin{array}{l}\text { Dummy if Plan Allows } \\
\text { Borrowing }\end{array}$}} & 0.505 & 0.487 & 0.039 \\
\hline & & (8.93) & (8.74) & $(7.58)$ \\
\hline \multirow{2}{*}{\multicolumn{2}{|c|}{$\begin{array}{l}\text { Dummy if Plan Allows } \\
\text { Hardship Withdrawals }\end{array}$}} & 0.128 & 0.140 & -0.004 \\
\hline & & $(1.08)$ & (1.19) & $(0.32)$ \\
\hline \multirow{3}{*}{\multicolumn{2}{|c|}{$\begin{array}{l}\text { Dummy if Plan Allows } \\
\text { Self-Directed } \\
\text { Investment }\end{array}$}} & 0.716 & 0.694 & 0.052 \\
\hline & & $(9.58)$ & $(9.31)$ & (7.49) \\
\hline & & & & \\
\hline \multirow{2}{*}{\multicolumn{2}{|c|}{$\begin{array}{l}\text { Dummy if Other } \\
\text { Traditional Pension }\end{array}$}} & 0.231 & 0.232 & 0.009 \\
\hline & & $(4.19)$ & $(4.27)$ & $(1.86)$ \\
\hline \multirow{3}{*}{\multicolumn{2}{|c|}{$\begin{array}{l}\text { Dummy if Plan Limit } \\
\text { Is Less than Federal } \\
\text { Limit }\end{array}$}} & 0.272 & 0.300 & 0.023 \\
\hline & & $(3.23)$ & $(3.51)$ & $(2.88)$ \\
\hline & & & & \\
\hline \multirow{2}{*}{\multicolumn{2}{|c|}{$\begin{array}{l}\text { Dummy if Plan has an } \\
\text { After-Tax Saving }\end{array}$}} & 0.472 & 0.459 & 0.031 \\
\hline & & $(8.21)$ & $(8.08)$ & $(6.03)$ \\
\hline
\end{tabular}




\begin{tabular}{|c|c|c|c|c|}
\hline Option & & & & \\
\hline $\begin{array}{l}\text { Dummy if Firm Offers } \\
\text { Retirement Seminar }\end{array}$ & & & $\begin{array}{l}0.071 \\
(1.17)\end{array}$ & $\begin{array}{l}0.004 \\
(0.65)\end{array}$ \\
\hline $\begin{array}{l}\text { Dummy if Firm Size is } \\
500 \text { or more }\end{array}$ & & & $\begin{array}{l}-0.079 \\
(1.45)\end{array}$ & $\begin{array}{l}-0.007 \\
(1.43)\end{array}$ \\
\hline $\begin{array}{l}\text { Dummy if Firm Size is } \\
250 \text { to } 499\end{array}$ & & & $\begin{array}{l}-0.052 \\
(0.60)\end{array}$ & $\begin{array}{l}-0.009 \\
(1.12)\end{array}$ \\
\hline Dummy if Union & & & $\begin{array}{l}-0.131 \\
(2.30)\end{array}$ & $\begin{array}{l}-0.015 \\
(2.87)\end{array}$ \\
\hline $\begin{array}{l}\text { Marginal-Tax- } \\
\text { Weighted Share of } \\
\text { Highly-Compensated } \\
\text { Employees }\end{array}$ & & & $\begin{array}{l}0.083 \\
(2.66)\end{array}$ & $\begin{array}{l}0.009 \\
(3.09)\end{array}$ \\
\hline $\begin{array}{l}\text { Number of Days of } \\
\text { Paid Sick Leave } \\
\text { Offered }\end{array}$ & & & $\begin{array}{l}0.004 \\
(2.04)\end{array}$ & $\begin{array}{l}0.000 \\
(1.05)\end{array}$ \\
\hline $\begin{array}{l}\text { Number of Days of } \\
\text { Paid Vacation Offered }\end{array}$ & & & $\begin{array}{l}0.008 \\
(0.58)\end{array}$ & $\begin{array}{l}0.000 \\
(0.33)\end{array}$ \\
\hline $\begin{array}{l}\text { Dummy if Long-Term } \\
\text { Disability Offered }\end{array}$ & & & $\begin{array}{l}0.140 \\
(2.47)\end{array}$ & $\begin{array}{l}0.011 \\
(2.07)\end{array}$ \\
\hline $\begin{array}{l}\text { Dummy if Group Term } \\
\text { Life Insurance Offered }\end{array}$ & & & $\begin{array}{l}0.055 \\
(1.06)\end{array}$ & $\begin{array}{l}0.003 \\
(0.72)\end{array}$ \\
\hline $\begin{array}{l}\text { Nu mber of Health } \\
\text { Insurance Plans } \\
\text { Offered }\end{array}$ & & & $\begin{array}{l}0.081 \\
(1.42)\end{array}$ & $\begin{array}{l}0.010 \\
(1.97)\end{array}$ \\
\hline $\begin{array}{l}\text { Nu mber of Retiree } \\
\text { Health Insurance Plans } \\
\text { Offered }\end{array}$ & & & $\begin{array}{l}-0.098 \\
(1.66)\end{array}$ & $\begin{array}{l}-0.010 \\
(1.86)\end{array}$ \\
\hline Constant & $\begin{array}{l}0.304 \\
(0.67)\end{array}$ & $\begin{array}{r}-1.625 \\
(4.17)\end{array}$ & $\begin{array}{l}-1.752 \\
(4.42)\end{array}$ & $\begin{array}{l}-0.171 \\
(4.69)\end{array}$ \\
\hline $\begin{array}{l}\text { Number of } \\
\text { Observations }\end{array}$ & 1044 & 1044 & 1044 & 1042 \\
\hline Other Controls : & & & & \\
\hline Demographics & Yes & Yes & Yes & Yes \\
\hline Health Variables & Yes & Yes & Yes & Yes \\
\hline Risk Characteristics & Yes & Yes & Yes & Yes \\
\hline
\end{tabular}


Table 7. Parameter Estimates from Specifications Similar to Previous Literature, $\mathrm{t}$-Statistics in Parentheses

\begin{tabular}{|c|c|c|c|c|}
\hline \multirow[b]{3}{*}{$\begin{array}{l}\text { Explanatory } \\
\text { Variables }\end{array}$} & (1) & (2) & (3) & (4) \\
\hline & \multicolumn{4}{|c|}{ Estimator } \\
\hline & Probit & OLS & OLS & $\begin{array}{c}\text { One-Limit } \\
\text { Tobit }\end{array}$ \\
\hline $\begin{array}{l}\text { Dummy if Plan } \\
\text { Offers a Match }\end{array}$ & $\begin{array}{l}0.304 \\
(1.74)\end{array}$ & $\begin{array}{l}589.3 \\
(2.83)\end{array}$ & $\begin{array}{l}536.5 \\
(2.61)\end{array}$ & $\begin{array}{l}868.7 \\
(2.65)\end{array}$ \\
\hline $\begin{array}{l}\text { First-Dollar } \\
\text { Match Rate }\end{array}$ & $\begin{array}{l}0.230 \\
(1.01)\end{array}$ & $\begin{array}{l}-229.2 \\
(0.85)\end{array}$ & $\begin{array}{l}-135.8 \\
(0.51)\end{array}$ & $\begin{array}{c}7.0 \\
(0.02)\end{array}$ \\
\hline $\begin{array}{l}\text { Earnings } \\
\text { (thousands) }\end{array}$ & $\begin{array}{l}0.000 \\
(2.73)\end{array}$ & $\begin{array}{c}0.050 \\
(14.88)\end{array}$ & $\begin{array}{l}0.036 \\
(0.97)\end{array}$ & $\begin{array}{l}0.173 \\
(2.28)\end{array}$ \\
\hline Age & $\begin{array}{l}2.312 \\
(0.61)\end{array}$ & $\begin{array}{c}16.9 \\
(1.58)\end{array}$ & $\begin{array}{l}837.5 \\
(0.19)\end{array}$ & $\begin{array}{l}2981.7 \\
(0.39)\end{array}$ \\
\hline Age Squared & $\begin{array}{l}-0.057 \\
(0.52)\end{array}$ & & $\begin{array}{l}-12.3 \\
(0.09)\end{array}$ & $\begin{array}{l}-62.2 \\
(0.28)\end{array}$ \\
\hline Age Cubed & $\begin{array}{l}0.001 \\
(0.44)\end{array}$ & & $\begin{array}{l}0.035 \\
(0.02)\end{array}$ & $\begin{array}{l}0.539 \\
(0.19)\end{array}$ \\
\hline Age Quartic & $\begin{array}{l}-0.000 \\
(0.37)\end{array}$ & & $\begin{array}{l}0.000 \\
(0.04)\end{array}$ & $\begin{array}{l}-0.002 \\
(0.12)\end{array}$ \\
\hline Spouse's Age & $\begin{array}{l}-0.133 \\
(0.85)\end{array}$ & $\begin{array}{c}9.2 \\
(1.39)\end{array}$ & $\begin{array}{l}-98.1 \\
(0.53)\end{array}$ & $\begin{array}{l}-273.4 \\
(0.89)\end{array}$ \\
\hline $\begin{array}{l}\text { Spouse's Age } \\
\text { Squared }\end{array}$ & $\begin{array}{l}0.006 \\
(0.65)\end{array}$ & & $\begin{array}{c}2.2 \\
(0.22)\end{array}$ & $\begin{array}{c}9.8 \\
(0.59)\end{array}$ \\
\hline $\begin{array}{l}\text { Spouse's Age } \\
\text { Cubed }\end{array}$ & $\begin{array}{l}-0.000 \\
(0.48)\end{array}$ & & $\begin{array}{l}0.004 \\
(0.02)\end{array}$ & $\begin{array}{l}-0.105 \\
(0.35)\end{array}$ \\
\hline $\begin{array}{l}\text { Spouse's Age } \\
\text { Quartic }\end{array}$ & $\begin{array}{l}0.000 \\
(0.35)\end{array}$ & & $\begin{array}{c}-0.0001 \\
(0.21)\end{array}$ & $\begin{array}{c}0.0001 \\
(0.15)\end{array}$ \\
\hline Dummy if Female & $\begin{array}{l}0.294 \\
(2.60)\end{array}$ & $\begin{array}{l}358.1 \\
(2.94)\end{array}$ & $\begin{array}{l}285.7 \\
(2.11)\end{array}$ & $\begin{array}{l}597.8 \\
(2.67)\end{array}$ \\
\hline Dummy if White & $\begin{array}{l}0.256 \\
(2.33)\end{array}$ & $\begin{array}{l}274.5 \\
(2.04)\end{array}$ & $\begin{array}{l}249.3 \\
(1.88)\end{array}$ & $\begin{array}{l}576.8 \\
(2.57)\end{array}$ \\
\hline $\begin{array}{l}\text { Number of } \\
\text { Children }\end{array}$ & $\begin{array}{l}0.012 \\
(0.25)\end{array}$ & $\begin{array}{l}-21.0 \\
(0.37)\end{array}$ & $\begin{array}{l}-10.1 \\
(0.18)\end{array}$ & $\begin{array}{c}10.3 \\
(0.11)\end{array}$ \\
\hline Education (Years) & $\begin{array}{l}0.052 \\
(2.73)\end{array}$ & $\begin{array}{l}108.3 \\
(4.80)\end{array}$ & $\begin{array}{c}92.3 \\
(4.08)\end{array}$ & $\begin{array}{l}160.3 \\
(4.18)\end{array}$ \\
\hline
\end{tabular}




\begin{tabular}{lcccc}
\hline & $(1)$ & $(2)$ & $(3)$ & $(4)$ \\
\hline Spouse's & 0.026 & -0.5 & 26.5 & 53.7 \\
Education (Years) & $(1.39)$ & $(0.02)$ & $(1.20)$ & $(1.44)$ \\
& & & & \\
Dummy if Married & -0.143 & -341.0 & -77.4 & -218.9 \\
& $(0.51)$ & $(1.09)$ & $(0.23)$ & $(0.40)$ \\
& & & -18996.1 & -56891.1 \\
Constant & -37.089 & -3310.1 & $(0.33)$ & $(0.58)$ \\
& $(0.78)$ & $(4.78)$ & Yes & Yes \\
Earnings Entered & Yes & No & & \\
as a Quartic & & & 0.34 & \\
& & 0.31 & & \\
$R^{2}$ & & &
\end{tabular}

Note: In columns 2 and 3, earnings are entered as a quartic function and just the parameter estimate on the linear term is shown above. 
Table 8. Instrumental Variable Parameter Estimates of 401(k) Contributions for Selected Variables, Controlling for Demographics, Rate of Time Preference,

Firm and Plan Specific Characteristics, Standard Errors in Parentheses

\begin{tabular}{|c|c|c|c|c|}
\hline Explanatory Variable & $(1)$ & $(2)$ & (3) & (4) \\
\hline \multicolumn{5}{|c|}{ A. Instrumental Variables Tobit Parameter Estimates } \\
\hline$\Delta p$ & $\begin{array}{c}344.16 \\
(870.66)\end{array}$ & $\begin{array}{l}-355.64 \\
(899.28)\end{array}$ & $\begin{array}{c}-82.39 \\
(781.84)\end{array}$ & $\begin{array}{c}-203.11 \\
(871.08)\end{array}$ \\
\hline$\omega \Delta p$ & $\begin{array}{l}134.13 \\
(32.09)\end{array}$ & $\begin{array}{l}120.15 \\
(31.12)\end{array}$ & $\begin{array}{l}133.17 \\
(34.78)\end{array}$ & $\begin{array}{l}134.57 \\
(32.42)\end{array}$ \\
\hline$y^{v} \Delta p$ & $\begin{array}{c}-264.14 \\
(326.59)\end{array}$ & $\begin{array}{c}-54.33 \\
(347.79)\end{array}$ & $\begin{array}{l}-126.11 \\
(309.83)\end{array}$ & $\begin{array}{c}-49.80 \\
(297.62)\end{array}$ \\
\hline$\kappa$ & $\begin{array}{c}-210.47 \\
(1148.08)\end{array}$ & $\begin{array}{c}598.58 \\
(1056.68)\end{array}$ & $\begin{array}{c}283.63 \\
(1165.14)\end{array}$ & $\begin{array}{c}286.71 \\
(1115.26)\end{array}$ \\
\hline \multicolumn{5}{|l|}{ B. Controls } \\
\hline $\begin{array}{l}\text { Individual and Spouse's } \\
\text { Demographics and Discount Rate? }\end{array}$ & Yes & Yes & Yes & Yes \\
\hline $\begin{array}{l}401(\mathrm{k}) \text { and Other Pension } \\
\text { Characteristics? }\end{array}$ & Yes & Yes & Yes & Yes \\
\hline Fringe Benefits? & Yes & Yes & Yes & Yes \\
\hline $\begin{array}{l}\text { Census Division, Firm Size, Union, } \\
\text { and Tax-Weighted Share of Highly } \\
\text { Compensated Employees? }\end{array}$ & No & Yes & Yes & Yes \\
\hline $\begin{array}{l}\text { Individual and Spouse's Employer- } \\
\text { Provided Retirement Seminar and } \\
\text { Discussion with Co-Workers? }\end{array}$ & No & Yes & Yes & Yes \\
\hline $\begin{array}{l}\text { Interactions of Demographics and } \\
\text { Discount Rate? }\end{array}$ & No & No & Yes & Yes \\
\hline $\begin{array}{l}\text { Interactions of Demographics with } \\
\text { Plan Characteristics, Seminar, and } \\
\text { Fringe Benefits? }\end{array}$ & No & No & No & Yes \\
\hline C. Diagnostics & & & & \\
\hline Log Likelihood & -5325 & -5295 & -5256 & -5214 \\
\hline Sample Size & 1042 & 1042 & 1042 & 1042 \\
\hline $\begin{array}{l}p \text {-Value for Test of Hypothesis that } \\
\text { the Match Rate Has No Effect }\end{array}$ & 0.00001 & 0.00001 & 0.00001 & 0.00001 \\
\hline $\begin{array}{l}p \text {-Value for Test of Hypothesis that } \\
\text { the Net Wage Has No Effect }\end{array}$ & 0.00009 & 0.0001 & 0.0001 & 0.00009 \\
\hline
\end{tabular}


$p$-Value for Test of Hypothesis that

0.4186

0.8759

0.6840

0.8671

Full Income Has No Effect

$p$-Value for Test of Hypothesis that

0.00003

0.00003

0.00003

0.00003

the Relative After-Tax Price Has No

Effect

D. Instrumental Variable Tobit Elasticity with Respect to

Match Rate

Full Income

Net Wage

Relative After-Tax Price of 401(k) to IRA Saving

Match Rate

Full Income

Net Wage

Relative After-Tax Price of 401(k) to IRA Saving

Match Rate

Full Income

Net Wage

Relative After-Tax Price of 401(k) to

IRA Saving

E. Instrumental Variable Probit Elasticity with Respect to

$\begin{array}{lcccc}\text { Match Rate } & 0.24 & 0.20 & 0.20 & 0.21 \\ \text { Full Income } & -0.11 & -0.09 & -0.02 & -0.01 \\ \text { Net Wage } & 0.22 & 0.20 & 0.20 & -0.48 \\ \text { Relative After-Tax Price of 401(k) to } & -0.48 & -0.51 & -0.51 & \\ \text { IRA Saving } & & & & \\ \end{array}$

\begin{tabular}{llll}
\hline 0.27 & 0.20 & 0.27 & 0.27 \\
-0.08 & -0.02 & -0.04 & -0.02 \\
0.40 & 0.40 & 0.44 & 0.46 \\
-0.61 & -0.58 & -0.66 & -0.68
\end{tabular}

On the Extensive Margin

\begin{tabular}{|c|c|c|c|}
\hline 0.16 & 0.12 & 0.16 & 0.16 \\
\hline-0.05 & -0.01 & -0.02 & -0.01 \\
\hline 0.24 & 0.24 & 0.26 & 0.27 \\
\hline-0.36 & -0.34 & -0.39 & -0.40 \\
\hline \multicolumn{4}{|c|}{ On the Intensive Margin } \\
\hline 0.11 & 0.08 & 0.11 & 0.11 \\
\hline
\end{tabular}

$-0.03$

$-0.01$

$-0.02$

$-0.01$

0.16

0.16

0.18

0.19

$-0.25$

$-0.23$

$-0.27$

$-0.28$

\section{Total}




\begin{abstract}
Note: Note: Panel A of this table presents parameter estimates for the first four terms in equation (33) in the text. For all columns, the upper contributions limits are individual-varying, as described in the text. All columns assume prices, net wage, and virtual income as endogenous, and the IV Tobit estimator of Newey (1987) is used, employing the instrumental variables discussed in the text. Panel D presents estimates of elasticities of $401(\mathrm{k})$ contributions based on the IV Tobit parameter estimates in panel A evaluated at the sample mean. The sample mean $401(\mathrm{k})$ budget share is 1.5 percent. The elasticities on the extensive and intensive margins were calculated using the McDonald-Moffitt decomposition. Panel E presents estimates from the IV Probit model of probability of a positive 401(k) contribution using the same specifications.
\end{abstract}


Table 9. Robustness of the Match Rate Elasticity to Alternative Specifications

\begin{tabular}{lccccc}
\hline Explanatory Variable & Margin & $(1)$ & $(2)$ & $(3)$ & $(4)$ \\
\hline $\begin{array}{l}\text { A. Random Effects Estimates with } \\
\text { Linear Marginal Utility }\end{array}$ & & & & & \\
& Total & 0.19 & 0.16 & 0.25 & 0.26 \\
& Extensive & 0.11 & 0.09 & 0.15 & 0.15 \\
& Intensive & 0.08 & 0.07 & 0.10 & 0.11 \\
B. Quadratic Marginal Utility & Total & 0.17 & 0.16 & 0.22 & 0.19 \\
& Extensive & 0.10 & 0.10 & 0.14 & 0.12 \\
& Intensive & 0.07 & 0.07 & 0.09 & 0.07 \\
C. Logarithmic Marginal Utility & & & & 0.18 & 0.15 \\
& Total & 0.18 & 0.13 & 0.18 \\
& Extensive & 0.10 & 0.07 & 0.11 & 0.09 \\
& Intensive & 0.07 & 0.05 & 0.07 & 0.06 \\
\hline
\end{tabular}


Figure 1.

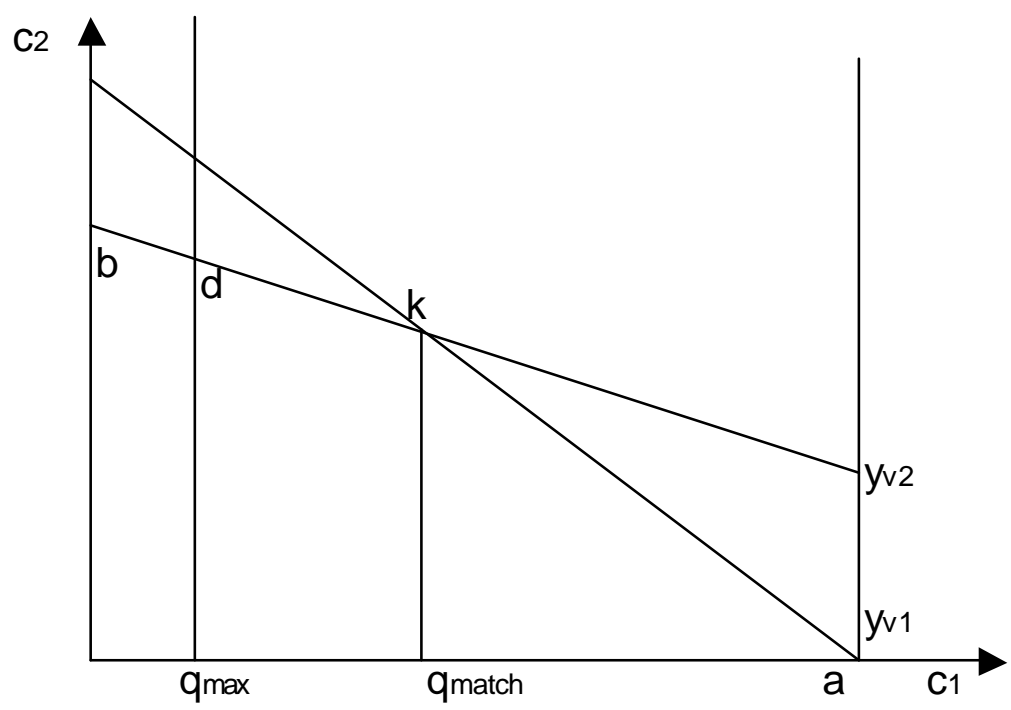


Figure 2.

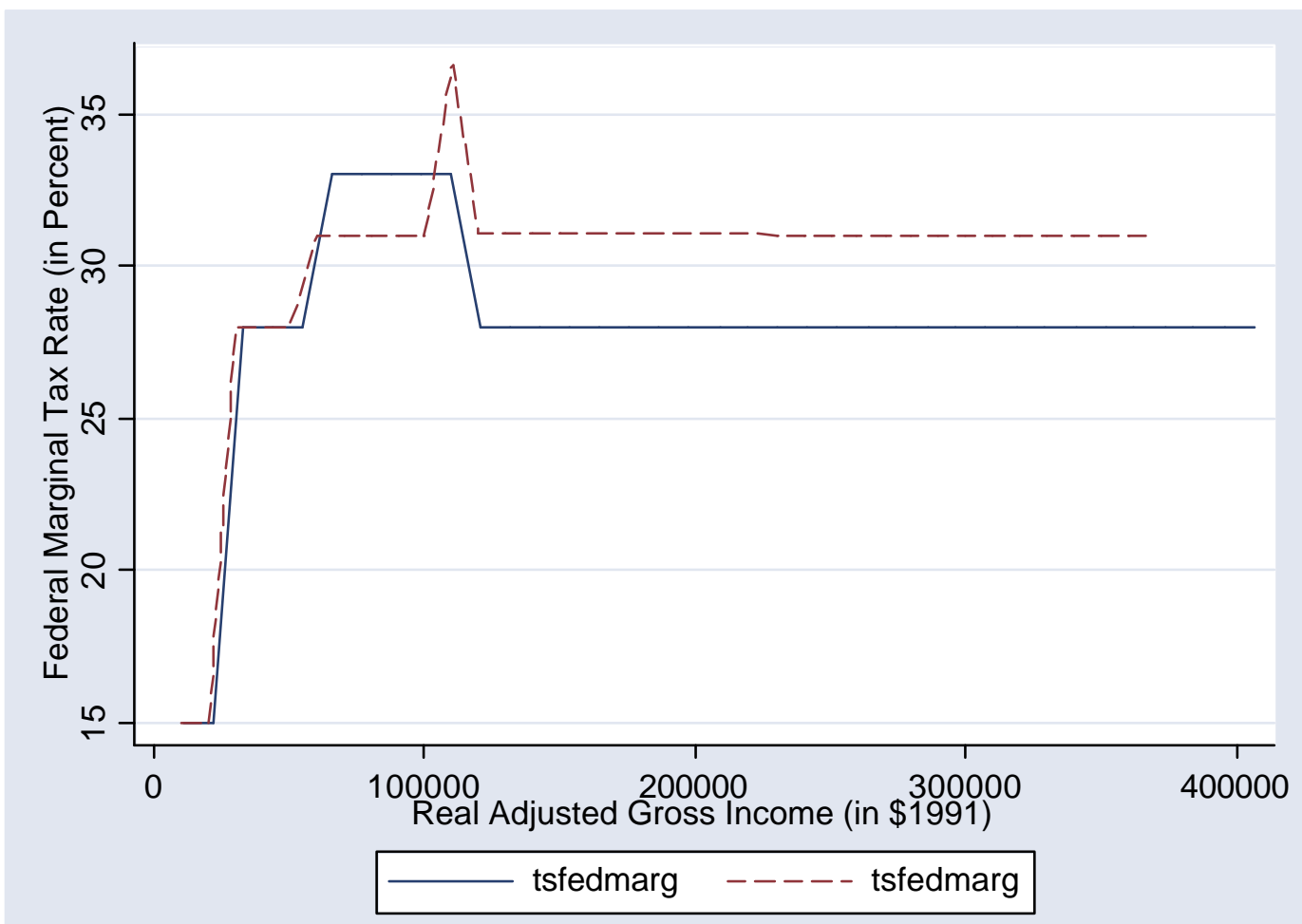




\section{RECENT WORKING PAPERS FROM THE}

\section{CENTER FOR RETIREMENT RESEARCH AT Boston COLLEGE}

Large, Small, International: Equity Portfolio Choices in a Large 401(k) Plan Julie Agnew and Pierluigi Balduzzi, May 2004

An Analysis of How Individuals React to Market Returns in One 401(k) Plan Julie Agnew, April 2004

The Effects of Health Insurance and Self-Insurance on Retirement Behavior

Eric French and John Bailey Jones, April 2004

Valuing Assets in Retirement Saving Accounts

James M. Poterba, April 2004

Lifetime Earnings, Social Security Benefits, and the Adequacy of Retirement Wealth Accumulation

Eric M. Engen, William G. Gale, and Cori Uccello, April 2004

The Effect of Social Security on Divorce and Remarriage Behavior Stacy Dickert-Conlin and Cristian Meghea, April 2004

Household Demand for Variable Annuities

Jeffrey R. Brown and James M. Poterba, March 2004

Lessons for an Aging Society: The Political Sustainability of Social Security Systems Vincenzo Galasso and Paola Profeta, March 2004

Choice and Other Determinants of Employee Contributions to Defined

Contribution Plans

Leslie E. Papke, March 2004

Linking Benefits to Marital Status: Race and Diminishing Access to Social Security Spouse and Widow Benefits in the U.S.

Madonna Harrington Meyer, Douglas A. Wolf, and Christine L. Himes, March 2004

Annuitization: Keeping Your Options Open

Irena Dushi and Anthony Webb, March 2004

Living Arrangements and Supplemental Security Income Receipt Among the Aged Melissa M. Favreault and Douglas A. Wolf, February 2004

All working papers are available on the Center for Retirement Research website

(http://www.bc.edu/crr) and can be requested by e-mail (crr@bc.edu) or phone (617-552-1762). 